\title{
TCA Cycle Rewiring as Emerging Metabolic Signature of Hepatocellular Carcinoma
}

\author{
Simona Todisco ${ }^{1}$, Paolo Convertini ${ }^{1}$, Vito Iacobazzi ${ }^{2}$ and Vittoria Infantino ${ }^{1, * \mathbb{D}}$ \\ 1 Department of Science, University of Basilicata, viale dell'Ateneo Lucano 10, 85100 Potenza, Italy; \\ simona.todisco@unibas.it (S.T.); paolo.convertini@gmail.com (P.C.) \\ 2 Department of Biosciences, Biotechnologies and Biopharmaceutics, University of Bari, via Orabona 4, \\ 70125 Bari, Italy; vito.iacobazzi@uniba.it \\ * Correspondence: vittoria.infantino@unibas.it; Tel.: +39-09-7120-6102
}

Received: 27 November 2019; Accepted: 23 December 2019; Published: 25 December 2019

\begin{abstract}
Hepatocellular carcinoma (HCC) is a common malignancy. Despite progress in treatment, HCC is still one of the most lethal cancers. Therefore, deepening molecular mechanisms underlying HCC pathogenesis and development is required to uncover new therapeutic strategies. Metabolic reprogramming is emerging as a critical player in promoting tumor survival and proliferation to sustain increased metabolic needs of cancer cells. Among the metabolic pathways, the tricarboxylic acid (TCA) cycle is a primary route for bioenergetic, biosynthetic, and redox balance requirements of cells. In recent years, a large amount of evidence has highlighted the relevance of the TCA cycle rewiring in a variety of cancers. Indeed, aberrant gene expression of several key enzymes and changes in levels of critical metabolites have been observed in many solid human tumors. In this review, we summarize the role of the TCA cycle rewiring in HCC by reporting gene expression and activity dysregulation of enzymes relating not only to the TCA cycle but also to glutamine metabolism, malate/aspartate, and citrate/pyruvate shuttles. Regarding the transcriptional regulation, we focus on the link between NF-kB-HIF1 transcriptional factors and TCA cycle reprogramming. Finally, the potential of metabolic targets for new HCC treatments has been explored.
\end{abstract}

Keywords: tricarboxylic acid (TCA) cycle rewiring; metabolic reprogramming; hepatocellular carcinoma (HCC); malate/aspartate shuttle (MAS); citrate/pyruvate shuttle; glutamine; NF- $\mathrm{kB}$; HIF1

\section{Introduction}

Hepatocellular carcinoma (HCC) is the most common primary liver cancer and the third leading cause of cancer-linked mortality, with an annual death rate exceeding 600,000 worldwide [1]. Viral infections (Hepatitis B and hepatitis C Viruses), toxins and drugs (e.g., alcohol and aflatoxin B1), non-alcoholic fatty liver disease, metabolic liver diseases, and diabetes are associated with HCC occurrence [2]. Despite progress in therapy and advanced screening of high-risk patients, many factors including the lack of effective therapeutic options for the advanced stages of the disease, the occurrence in the setting of liver disease, the aggressive and heterogeneous nature are responsible for the high mortality of HCC $[3,4]$. Thus, understanding molecular mechanisms underlying HCC pathogenesis and development is essential for innovative therapeutic interventions. Over recent years, increasing evidence has highlighted altered metabolic pathways as widespread as other cancer-associated features currently accepted as hallmarks of cancer [5]. Therefore, in addition to the classical hallmarks of cancer, the significance of some metabolites and/or key metabolic proteins have been taken into consideration for early diagnosis and better understanding of molecular mechanism of HCC.

Metabolic reprogramming is an essential hallmark of cancer, including HCC, as metabolic shifts represent a selective advantage for tumor growth, proliferation, and survival responding to 
the increased energy production, synthesis of macromolecules, and maintenance of redox balance. A well-known metabolic alteration in cancer cells is the elevated aerobic glycolysis, commonly referred as Warburg effect, which supports tumor growth [6]. However, only more recently the meaning and implications of this Warburg effect in cancer biology and its potential in diagnosis and drug targeting have begun to emerge. A markedly increased uptake of glucose in cancer, when compared to non-proliferating normal tissues, has been confirmed in a variety of tumors and positron emission tomography (PET) based on ${ }^{18}$ F-fluorodeoxyglucose $\left({ }^{18} \mathrm{~F}-\mathrm{FDG}\right)$ uptake is a widespread diagnostic tool in oncology, as well as in monitoring the treatment effectiveness [7]. Excessive glycolytic flux-if not employed for biosynthesis-diverts to lactate allowing NAD $^{+}$cytosolic production and avoiding both glycolysis slowdown and TCA cycle suppression by an immoderate mitochondrial supply of NADH [8].

Warburg misinterpreted the meaning of aerobic glycolysis attributing it to a damaged mitochondrial respiration, which drives cancer cells to rely on alternative ways for energy production [9]. Today it is well-known that during cancer pathogenesis and development, a rewiring of metabolic pathways rather than a simple dysfunction is occurring in mitochondria [10]. They are reprogrammed to supply building blocks for nucleic acids, lipids, and protein synthesis; therefore, being essential for cancer cell proliferation. Accordingly, the Warburg effect is not an adaptive condition but a tightly regulated metabolic state supporting an increased biosynthetic demand.

Together with glucose, glutamine also supports cancer cell growth providing carbon as well as reduced nitrogen for de novo synthesis of nitrogen-containing compounds such as nucleotides, glucosamine-6-phosphate, and non-essential amino acids. It has been reported that cultured cancer cells may require up to 100-fold molar excess of glutamine compared to other amino acids [11] and glutamine deprivation from the tumor environment has been found in a variety of tumorigenic contexts $[12,13]$. As matter of fact, ${ }^{18}$ F-labeled glutamine tracer seems to be promising especially for tumors developing in areas such as brain where a weighty use of glucose occurs [14]. By glutaminase (GLS) and then glutamate dehydrogenase (GDH) or amino acid transaminase reactions, glutamine can be converted into $\alpha$-ketoglutarate $(\alpha \mathrm{KG})$ thus representing the major anaplerotic substrate to replenish TCA cycle intermediates in proliferating cells [15]. Of note, glutamine-derived $\alpha \mathrm{KG}$ may also provide citrate by a reductive carboxylation [16].

In this metabolic rewiring, the movement of metabolites across the mitochondrial membrane might play a crucial role for tumor growth. For example, citrate - the first intermediate of TCA cycle-is exported from mitochondria to the cytosol through the mitochondrial citrate carrier (CIC) resulting vital for de novo biosynthesis of fatty acids dramatically raised in cancer cells [17]. An increased lipogenesis also produces saturated lipids less susceptible to lipid peroxidation as adaptation to oxidative stress [18]. Indeed, CIC transport inhibition blocks tumor growth and its activity is increased in HCC [19,20]. Enzymes of de novo fatty acid synthesis including ATP-citrate lyase (ACLY), acetyl-CoA carboxylase, and fatty acid synthase are also overexpressed in a wide variety of solid human tumors, including HCC [21]. Of note, citrate export represents a further protection of mitochondria from excessive glycolysis because any pyruvate entering TCA cycle is channeled into this way.

In addition to citrate, TCA cycle supplies other metabolic precursors including aspartate and succinate. Export of aspartate from mitochondria is essential for protein, purine, and pyrimidine biosynthesis in proliferating tumor cells. Aspartate is exported to the cytosol by the mitochondrial aspartate/glutamate carriers (AGC1 and AGC2) in exchange for glutamate and a proton [22]. This transport is part of the malate/aspartate shuttle (MAS) whose activity is crucial for the regeneration of cytosolic $\mathrm{NAD}^{+}$required for glycolysis. Very recently, cytosolic aspartate/glutamate carrier-derived aspartate has been described as an endogenous metabolic limitation for tumor growth, pointing out its role in cancer [23].

Succinate may function as a direct signaling messenger linking TCA cycle rewiring to tumorigenesis. In cancer cells, such as in innate immune cells [24], succinate moves outside the mitochondria via the dicarboxylic acid carrier and the voltage-dependent anion channel in the mitochondrial inner and 
outer membranes, respectively. Once in the cytosol, succinate inhibits some $\alpha$-ketoglutarate-dependent oxygenases, including oxygen-dependent prolyl hydroxylase (PHD) enzyme [25] that hydroxylates the Hypoxia Inducible Factor $1 \alpha$-subunit (HIF-1 $\alpha$ ) with subsequent proteosomal degradation. There is plenty of evidence that down-regulation as well as mutations of SDH genes, found in a variety of cancers, result in succinate accumulation, which inhibits HIF1-PHD, leading to HIF-stabilization and activation [26].

Thus, TCA cycle rewiring plays a central role in cancer cells being closely linked to the traffic of molecules between mitochondria and cytosol. Probably, its role in cancer metabolism, tumorigenesis, and cancer cell proliferation has been overlooked for a long time. In more recent years, in-depth analysis of cancer metabolism alterations has shown new roles for metabolic pathways, including TCA cycle, in tumors.

Considerably, this metabolic reprogramming results from altered gene expression of proteins involved in such pathways. Transcriptional regulation by transcriptional factors is responsible, at least in part, for these changes. Due to the growing evidence about role of the nuclear factor $\mathrm{kB}(\mathrm{NF}-\mathrm{kB})$ in inflammation-linked cancers and oncogenesis [27] and the emerging interplay between HIF1 and TCA cycle, we have chosen to focus on these two factors, taking into account that they are not the only factors linked to altered energy metabolism in cancer. Therefore, in this review we look at gene expression and activity of TCA cycle and related enzymes such as citrate/piruvate and malate/aspartate shuttles and their potential role in HCC.

\section{Inflammation and Role of NF- $\kappa$ B}

Molecular mechanisms linking chronic inflammation and cancer have been suggested in initiation, promotion, and progression of tumors [28]. Indeed, macrophages are recruited in a variety of tumors [29]. Inflammatory process may foster multiple hallmarks of tumors such as growth factors sustaining proliferation and survival factors limiting apoptosis [5]. Moreover, inflammation can be evident at the earliest stages of neoplastic transformation and can promote the development of incipient neoplasias [29]. Inflammatory cells, largely macrophages, release chemicals including reactive oxygen species (ROS), which are mutagenic for surrounding cancer cells, accelerating their development [30]. Subsequently, as the tumors progress toward malignancy, the macrophage phenotype changes from the "inflammatory" (M1) to the "trophic" (M2) phenotype promoting angiogenesis and tissue formation [31].

NF- $\kappa B$ plays a pivotal role in regulating immune responses and inflammation through five genes belonging to NF- $\kappa$ B transcription factor family: NF- $\mathrm{kB} 1$ (p50/p105), NF- $\kappa$ B2 (p52/p100), RelA (p65), c-Rel and RelB which produce seven proteins acting as dimers and with a Rel Homology Domain in their sequence [32]. NF-kB controls the expression of more than 200 target genes involved in various biological processes such as cell proliferation, apoptosis, response to free radicals, and ultraviolet irradiation.

A growing literature supports a major role for NF- $\mathrm{kB}$ in oncogenesis. In animal models, c-Rel homolog v-Rel induces avian lymphomas and leukemias being a highly oncogenic gene [33]. Furthermore, lymphomas, myelomas and leukemias may show genetic alterations of genes encoding for NF- $\mathrm{kB}$ subunits or other genes of the NF- $\mathrm{kB}$ signaling pathway leading to significant changes in NF- $\mathrm{KB}$ expression or activity [34-36]. High levels of c-Rel have been found in breast cancer where it has provided evidence for its function in carcinogenesis and in non-small cell lung carcinoma [37,38]. Moreover, RelA, RelB and NF- $\mathrm{kB} 1$ are constitutively activated in many human tumors. Increased nuclear translocation of RelA has been found in cervical and gastric carcinomas $[39,40]$.

In about $20 \%$ HCC occurrences, as in other human cancers, inflammation seems to be the underlying pathology [41]. As matter of fact, a rich literature supports the role of the chronic liver inflammation induced by viral infection, hepatotoxic drugs, and metabolic injury in HCC development. However, the landscape of the hepatic burgeoning inflammation is very complex involving many different cell types including hepatocytes, hepatic macrophages i.e., Kupffer cells (KCs) and hepatic stellate cells (HSCs). Chronically injured hepatocytes activate inflammatory pathways releasing 
chemokines and cytokines, which in turn attract KCs and HSCs [42]. In this context, HSCs become activated thus playing a critical role in fibrogenesis which may drive towards HCC [43].

In animal models, liver injury has been linked to NF- $\mathrm{kB}$ activation with the response being increased in females and in mice fed a high-fat diet [41]. Moreover, KCs show NF- $\mathrm{kB}$ activation in response to damaged hepatocytes resulting in secretion of TNF $\alpha$ and IL-6 proinflammatory cytokines strongly involved in promoting fibrosis and HCC [44]. Indeed, through various inflammatory mediators and a ight interplay KCs and hepatocytes induce HSC activation. A growing literature points up a significant role of HSCs in hepatic immune response and inflammation mediated by NF- $\mathrm{kB}$. In fact, p65 nuclear translocation is required for NO, TNF $\alpha$ and IL6 production in activated HSCs [45]. Of note, HSCs as well as hepatocytes and KCs also express TLR4-the most important LPS receptor-and activate NF- $\mathrm{kB}$ pathway following changes in gut microbiota, increased intestinal permeability and raised blood levels of LPS in mice fed a high-fat diet [46].

Although a moderate NF- $\mathrm{KB}$ hepatic activation represents a protective response against a persistent damage, its levels always increased may contribute to a chronic inflammatory state and to the development of hepatic insulin resistance [47].

However, it is not easy investigating NF- $\mathrm{KB}$ function in HCC pathogenesis and progression as NF- $\mathrm{kB}$ pathway inhibition may give apparently opposite effects in various animal models [48]. In this regard, conditional knockouts have been helpful showing that global deletion of IKK $\beta$ (NF-KB activator) restrains HCC development; conversely, NF- $\mathrm{kB}$ liver deletion enhances susceptibility of liver damage and HCC [27].

Interestingly, NF- $\mathrm{KB}$ function as regulator of metabolism has been recently investigated. Among NF- $\mathrm{kB}$ subunits, RelA has been clearly reported to have an important role in tumor cell metabolism [49]. Of note, through IкB $\alpha$ degradation, hypoxia also activates NF-kB [50] which binds to HIF- $1 \alpha$ gene promoter thus regulating its transcription (Figure 1) [51]. Through up-regulation of the metabolic SLC2A3 target gene, NF- $\mathrm{KB}$ may promote oncogenic transformation and enhance glycolysis [52]. Moreover, NF- $\mathrm{KB}$ regulates the transcription of aconitase 2, isocitrate dehydrogenase 3A (IDH3A), and succinyl-CoA ligase (SUCLA2) genes encoding three TCA cycle enzymes and IDH1 gene encoding a TCA-related protein in HCC cells (Figure 1) [53].

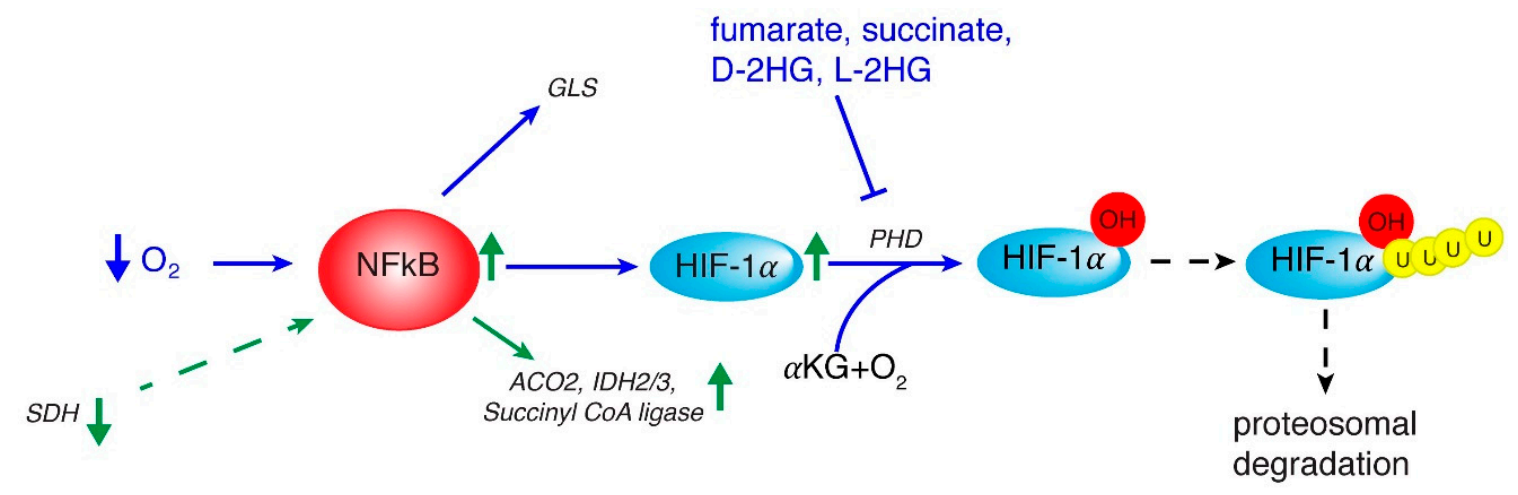

Figure 1. Interplay between NF-kB, HIF, and mitochondrial signals. The reported important role of $\mathrm{NF}-\mathrm{kB}$ in tumor cell metabolism may originate from hypoxia that activates NF- $\kappa \mathrm{B}$ which up-regulates $H I F-1 \alpha$ gene. In turn NF- $\mathrm{KB}$ activates glutamine metabolism via glutaminase (GLS) and TCA cycle by ACO2 (aconitase isoform 2), IDH 2/3 (isocitrate dehydrogenase isoform 2 and 3) and Succiyll CoA ligase genes. HIF- $1 \alpha$ stabilization takes place via L-2-HG, D-2-HG, succinate and fumarate which regulate PHD (oxygen-dependent prolyl hydroxylase) and subsequent HIF- $1 \alpha$ proteosomal degradation. Events occurring in HCC are marked by green arrows.

\section{HIF in Regulating Metabolic Rewiring}

Hypoxia inducible factors (HIFs) have a crucial role in adaptive response to hypoxia. HIFs transcription factors are made of an $\alpha$ subunit (oxygen-dependent) and a $\beta$ subunit constitutively 
expressed-also known as aryl hydrocarbon receptor nuclear translocator (Arnt) [54]. The human genome contains three genes encoding $\alpha$ subunits (HIF- $1 \alpha$, HIF- $2 \alpha$, and HIF- $3 \alpha$ ) and three $\beta$ subunits (Arnt1, Arnt2, and Arnt3). HIF- $1 \alpha$ is the most expressed isoform and drives the acute response to hypoxia, while HIF- $2 \alpha$ has a main role during chronic hypoxia. HIF-3 $\alpha$ is less well characterized probably because of the presence of multiple HIF-3 $\alpha$ variants [55]. In normally oxygenated tissues, $\alpha$-subunits are rapidly degraded by oxygen-dependent prolyl hydroxylases (PHDs) and subsequent ubiquitination. PHDs are members of $\alpha$-ketoglutarate-dependent dioxygenase family that function via oxidative decarboxylation of $\alpha \mathrm{KG}$ in the presence of $\mathrm{Fe}^{2+}$ and $\mathrm{O}_{2}$ with hydroxylation of HIF- $1 \alpha$ at two conserved proline residues with subsequent proteosomal degradation. When oxygen availability decreases, PHD inactivation leads to HIF- $\alpha$ stabilization and its nuclear import. Once in the nucleus, HIF- $\alpha$ dimerizes with a $\beta$ subunit and activates the hypoxic response through transcriptional up-regulation of target genes [56]. Significantly, reduced concentration of oxygen in many human cancers [57] — compared to adjacent normal tissues—activates HIF $\alpha$. Among HIFs, HIF-1 is the master regulator of the metabolic reprogramming occurring in cancer cells. HIF-1 promotes glucose catabolism through aerobic glycolysis and thus shifting glucose away from the TCA cycle by up-regulating the transcription of SLC2A1 and SLC2A3, encoding glucose transporters GLUT1 and GLUT3, respectively, hexokinase, the first enzyme of the glycolytic pathway, pyruvate kinase and lactate dehydrogenase A (LDHA) genes [58]. Furthermore, in the presence of low oxygen, HIF-1 transactivates PDK1 gene, encoding pyruvate dehydrogenase kinase 1, which phosphorylates and inhibits pyruvate dehydrogenase (PDH) complex thus reducing mitochondrial acetyl-CoA and increasing both pyruvate and lactate levels [59]. This metabolic condition induces HIF-1 $\alpha$ gene expression suggesting the existence of a positive feedback loop supporting a cancerous metabolic phenotype where HIF-1 induction leads to PDK activity, elevated levels of pyruvate and lactate, and further increase in HIF-1 activity [60]. Increased levels of ROS also induce HIF-1 $\alpha$ activation which in turn up-regulates its target genes fostering tumorigenesis.

Besides an oxygen-dependent mechanism, HIF-1 function is mediated by phosphatidylinositol 3-kinase and ERK mitogen activated protein kinase pathways, which promote cell growth and up-regulate HIF-1 $\alpha$ translation [61].

High HIF-1 $\alpha$ expression levels have been correlated with poor prognosis in patients with HCC [62]. Furthermore, increased HIF-1 $\alpha$ activity in HCC samples has been associated with worse overall survival rates and lower response to external beam radiotherapy, thus suggesting HIF- $1 \alpha$ as a predictive biomarker of treatment outcomes [63]. Of note, as for many cancers, there is a relationship between HIF-1 $\alpha$ activity and resistance to drug-induced apoptosis of HCC cells [64]. Suppression of mitochondrial OXPHOS by up-regulation of glycolytic genes through HIF-1 $\alpha$ was found to significantly correlate with a more aggressive HCC phenotype [65]. Intriguingly, HIF-1 $\alpha$ activity is tightly controlled by TCA cycle signals since TCA cycle intermediates such as succinate, fumarate and $\alpha \mathrm{KG}$ as well as the related oncometabolite L-2 hydroxyglutarate (L-2-HG) regulate HIF- $1 \alpha$ proteosomal degradation (Figure 1). These findings highlight new features of HIF-1 $\alpha$ function in metabolic reprogramming and suggest a complex interplay between HIF- $1 \alpha$ and TCA cycle rewiring in cancers, including HCC.

\section{TCA Cycle and Related Enzymes in HCC}

Several nuclear genes encode enzymes catalyzing TCA cycle biochemical reactions. It is well-known that through a series of cyclic reactions, TCA cycle is involved not only in energy production and electron transfer processes, but also in synthesis of intermediates which are used as building blocks for macromolecules. Fuel feeding of TCA cycle differs in normal and cancer cells. A growing body of evidence indicates a widespread dysregulation of TCA cycle and related enzymes either at expression or activity level in cancers such as HCC frequently related to cell transformation and progression. 


\subsection{Citrate Synthase}

The human gene encoding citrate synthase (CS) maps to chromosome 12 (12q13.3). CS localizes in the mitochondrial matrix and catalyzes the synthesis of citrate from acetyl-CoA and oxaloacetate (OAA), thus regenerating CoA. This is the first step and the rate-limiting reaction of the TCA cycle [66]. CS presents either up-regulation or increased enzymatic activity in various cancer types such as ovarian and pancreatic cancer $[67,68]$. Noteworthy, CS enzyme activity has been reported to be increased in HCC [69]. More recently, RNAseq analysis—then verified in multiple microarray data sets-identified CS overexpression among unique 22-carbon-metabolism-gene signature of HCC [70]. Furthermore, Zhang et al. have also demonstrated that CS knockdown strongly decreases HCC cell proliferation and hepatospheroid formation in low-glucose condition when compared to respective controls. Since HCC is associated with a metabolic reprogramming toward raised glycolysis and lipogenesis, increased CS gene expression and activity can provide cytosolic substrate for membrane lipid synthesis. According to the metabolic function of CS in HCC, Gao et al. found increased levels of citrate in HCC samples than healthy controls [71]. These data point out CS gene silencing or inhibition as a potential way to partially reduce the malignant phenotype of HCC.

\subsection{Isocitrate Dehydrogenase}

The isocitrate dehydrogenase (IDH) family consists of three isoforms (IDH1, IDH2, and IDH3) responsible for the decarboxylation of isocitrate to $\alpha \mathrm{KG}$. The cytosolic and peroxisomal IDH1, encoded by IDH1 gene on chromosome 2, catalyzes both the oxidative decarboxylation of isocitrate to $\alpha \mathrm{KG}$ thus reducing $\mathrm{NADP}^{+}$to NADPH and the reductive carboxylation of $\alpha \mathrm{KG}$-that is the reverse reaction-to isocitrate with concomitant oxidation of NADPH to NADP ${ }^{+}$. IDH2 mitochondrial isoform is encoded by IDH2 gene mapping to chromosome 15q26.1 and catalyzes the same reversible reaction as described for IDH1 [72]. IDH1 and IDH2 isoforms work as homodimers [73] while IDH3 is an heterotetramer made up of two alpha subunits (IDH3A), one beta subunit (IDH3B), and one gamma subunit (IDH3G) [74]. Unlike IDH1 and IDH2, IDH3 has a well-established role in TCA cycle catalyzing the irreversible conversion of isocitrate to $\alpha \mathrm{KG}$ while reducing $\mathrm{NAD}^{+}$to NADH. IDH1 and/or IDH2 mutations occur in glioma, and rarely in other cancers [75,76]. Of note, a just published work-by re-clustering and analyzing a genomic datasets including 196 patients from The Cancer Genome Atlas group-identified a more aggressive subset of HCC patients showing IDH1/2 mutations status and a worse survival than the other subsets [77]. These mutations result in the gained function producing the oncometabolite D-2-hydroxyglutarate (D-2-HG), which induces decreased levels of 5-hydroxymethylcytosine (5-HmC) by inhibiting Ten-eleven translocation (TET) family of 5-methylcitosine (5-mC) hydroxylases, an $\alpha \mathrm{KG}$ dependent dioxygenase (Figure 2) [78]. Furthermore, IDH3A has been found up-regulated in HCC cell lines treated with a combination of celecoxib and sorafenib, two drugs showing synergistic anti-proliferative and pro-apoptotic effects on HCC cells [79]. The metabolic impact of IDH1/2 mutations as well as IDH3A down-regulation in HCC could be linked to a reduced NADPH production, which results insufficient to maintain a favorable GSH:GSSG ratio thus increasing steady-state ROS and in turn oxidation of cellular components and DNA mutation rate, as already reported for others cancers involving IDH1/2 mutations [80,81]. 


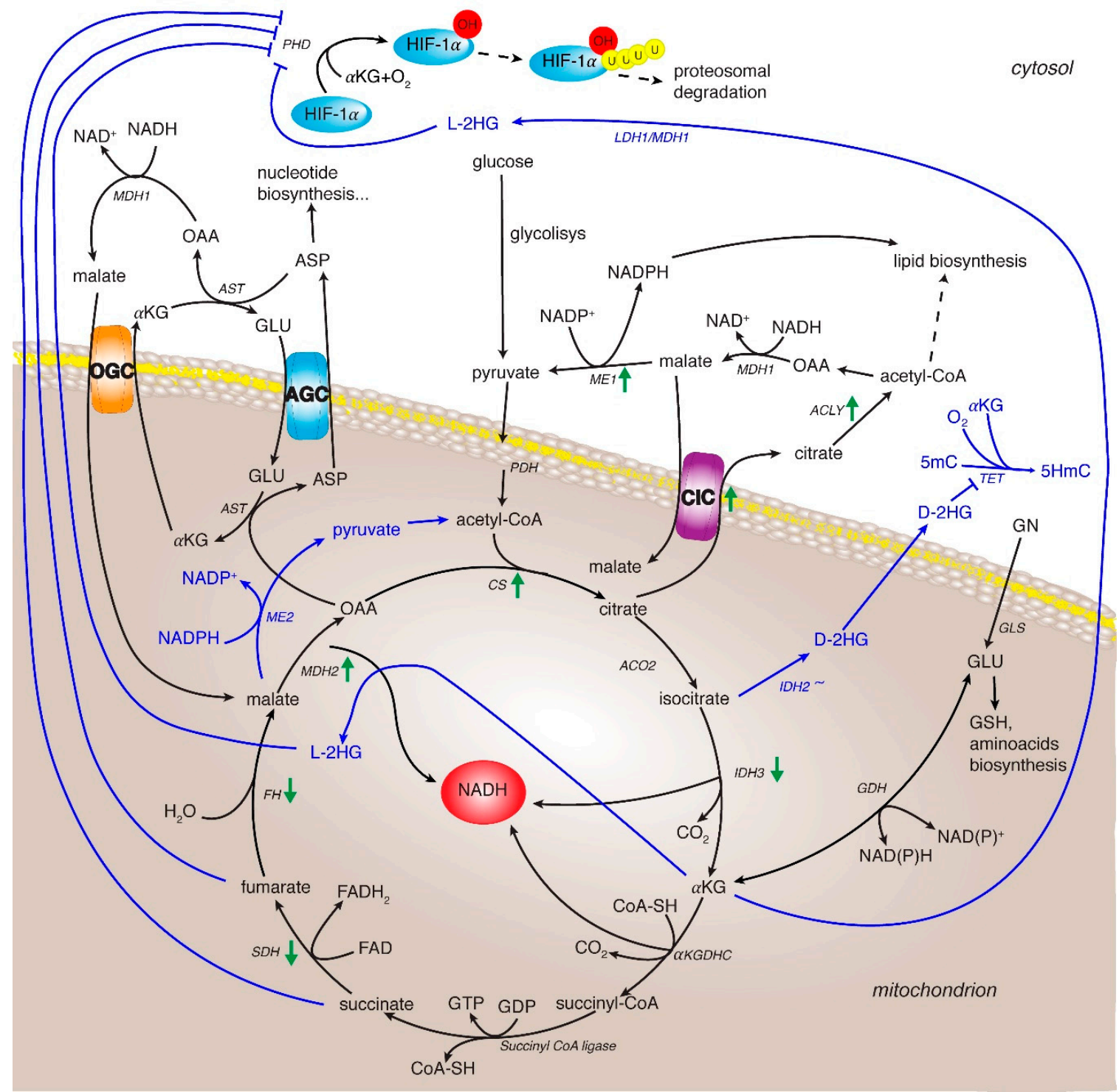

Figure 2. TCA cycle rewiring and mitochondrial signaling in cancer and HCC. The TCA cycle metabolic flux is represented by black arrows and specific enzymes. Three of them catalyze irreversible reactions: the citrate synthase, the isocitrate dehydrogenase 3 and the $\alpha$-ketoglutarate dehydrogenase complex. Blue lines indicate the reprogramming of metabolic reactions in cancer. Green arrows indicate up- and down-regulation of expression and/or activity of TCA cycle and related enzymes in HCC. Enzyme abbreviations: CS: citrate synthase; ACO2: aconitase isoform 2; IDH2/3: isocitrate dehydrogenase isoforms 2 and 3; $\alpha \mathrm{KGDHC}$ : $\alpha \mathrm{KG}$ dehydrogenase complex; $\mathrm{SDH}$ : succinate dehydrogenase; $\mathrm{FH}$ : fumarate hydratase; MDH1 and 2: malate dehydrogease isoform 1 and 2; $\mathrm{PDH}$ : pyruvate dehydrogenase; GLS: glutaminase, GDH: glutamate dehydrogenase; CIC: citrate carrier; AGC: aspartate/glutamate carrier; OGC: oxoglutarate carrier; ACLY: ATP-citrate lyase; ME1 and 2: malic enzyme isoform 1 and 2; AST: aspartate aminotransferase; PHD: oxygen-dependent prolyl hydroxylase; TET: Ten-eleven translocation family protein. Metabolite abbreviations: 2-L-HG (2-L-hydroxyglutarate) and D-2-HG (2-D-hydroxyglutarate), 5-mC: 5-methylcitosine; 5HmC: 5-hydroxymethylcytosine; OAA: oxaloacetate; $\alpha \mathrm{KG}$ : $\alpha$-ketoglutarate; ASP: aspartate; GLU: glutamate.

\section{3. $\alpha$-Ketoglutarate Dehydrogenase Complex}

The $\alpha$-ketoglutarate dehydrogenase complex (KGDHC) is a TCA cycle enzymatic complex that catalyzes the synthesis of succinyl-CoA via decarboxylation of $\alpha \mathrm{KG}$. This complex is formed from three proteins present in multiple copies: $\alpha$-ketoglutarate dehydrogenase (E1k subunit, EC 1.2.4.2), 
dihydrolipoamide succinyltransferase (E2k subunit, EC 2.3.1.12), and dihydrolipoamide dehydrogenase (E3 subunit, EC 1.6.4.3), and requires five cofactors: thiamine pyrophosphate, lipoic acid, coenzyme $\mathrm{A}, \mathrm{FAD}$, and $\mathrm{NAD}^{+}$. In the reaction catalyzed from KGDHC, E1k transfers two electrons from $\alpha \mathrm{KG}$ to the lipoyl group which is bound to E2k subunit. E3 subunit catalyzes the oxidation of reduced lipoyl group of E2k transferring the pair of electrons to the prosthetic group FAD and finally to $\mathrm{NAD}^{+}$, forming NADH. The E1k and E3 subunits are noncovalently bound to a core formed by E2k subunits [82,83]. KGDHC is activated by low concentrations of $\mathrm{Ca}^{2+}\left(10^{-7}-10^{-5} \mathrm{M}\right)$ and ADP ( $\sim 10^{-4} \mathrm{M}$ for half-maximum activation) [84,85], and it is inhibited by high NADH and its own product, succinyl-CoA [86-88].

Recently, a KGDHC alteration was related to HIF-1 $\alpha$ stabilization [89]. In normoxia HIF-1 $\alpha$ levels are maintained very low due to proteosomal degradation after hydroxylation by PHDs, $\alpha$-ketoglutarate dependent dioxygenases. Interestingly, the disruption or inhibition of KGDHC function may cause a conversion of $\alpha \mathrm{KG}$ to the oncometabolite L-2 hydroxyglutarate (L-2-HG) via spurious activity of LDHA and MDH1 in the cytosol, and via MDH2 in the mitochondria (Figure 2) [90]. Consequently, NADH accumulation and chain respiratory alteration facilitate this conversion. L-2-HG was the predominant enantiomer synthesized in these conditions and is the only compound able to inhibit PHDs with a stabilization of HIF- $1 \alpha$ [89]. Thus, $\alpha$ KG-dependent PHDs would be regulated by L-2-HG/ $\alpha$ KG ratio as $\alpha \mathrm{KG}$ supplementation or KGDHC inhibition leads to a low increase of L-2-HG levels in normoxia condition, and high increase in hypoxia condition [91]. In this context, $\alpha \mathrm{KG}$ accumulation promotes the formation of L-2-HG thus regulating PDH function and in turn HIF- $1 \alpha$ stability.

Of note, KGDHC has been also found in the nucleus of human cell lines bound to lysine acetyltransferase 2A (KAT2A, also known as GCN5) in the promoter regions of genes and the resulting complex acts as a histone $\mathrm{H} 3$ succinyltransferase. When $\alpha-\mathrm{KGDH}$ complex does not enter the nucleus, or KAT2A gene expression is reduced, inhibition of tumor cell proliferation and tumor growth was observed [92].

\subsection{Succinate Dehydrogenase}

Succinate dehydrogenase (SDH) complex, localized in the inner mitochondrial membrane, is composed of four nuclear-encoded subunits (SDHA, SDHB, SDHC, and SDHD). This highly conserved heterotetrameric enzyme catalyzes the oxidation of succinate to fumarate while simultaneously reducing $\mathrm{FAD}$ to $\mathrm{FADH}_{2}$ with subsequent transfer of electrons to ubiquinone. Known as mitochondrial respiratory chain complex II, SDH is the only complex which takes part in both TCA cycle and the electron transport chain and unlike most of the TCA cycle enzymes, does not show a cytosolic counterpart. Moreover, SDH is the only respiratory chain complex consisting of subunits totally encoded by nuclear genes mapping at chromosome bands 5p15 (SDHA), 1p36 (SDHB), 1q21 (SDHC), 11q23 (SDHD), 19q13 (SDHAF1), and 11q12 (SDHAF2), respectively [93]. Mutations in genes encoding different subunits of SDH have been associated with succinate accumulation and are causative of hereditary paraganglioma and pheochromocytoma [94]. The germline heterozygous mutations predisposing to hereditary paraganglioma and pheochromocytoma cause inactivation of the protein function. However, the neoplastic transformation takes place when there is the loss of the remaining wild type allele in the somatic cells (loss of heterozygosity) inducing the complete loss of SDH function. Thus, SDH is classified as a classical tumor suppressor gene [95].

Mutations in SDH genes were identified in several other cancers including thyroid, gastrointestinal stromal, neuroblastoma, renal and ovarian cancer [96]. SDHA and SDHB genes have also been found down-regulated in HCC [97]. Additionally, SDHB low expression levels in patients with HCC induced a metabolic shift from aerobic respiration to glycolysis and were associated with advanced tumor stage and poor survival rate [98].

Very recently, Li et al., investigating the expression levels of the genes encoding SDH subunits found a significant down-regulation of all four subunits which results in reduced SDH activity and 
increased ROS and succinate levels in HCC. Moreover, deficient SDHC activity promotes HCC cell growth and migration as well as NF- $\mathrm{kB}$ signaling [99].

The down-regulation of one or more SDH subunits associated with a decrease of SDH activity in HCC - reported from a growing literature in recent years-explains the accumulation of succinate also observed in HCC [71]. Increased levels of succinate activate HIF-1 which in turn up-regulates metabolic genes switching to the Warburg effect [26].

Interestingly, SDH activity is also impaired in injured hepatocytes thus inducing increased intrahepatic levels of succinate. The latter has been reported to activate HSCs through the membrane receptor GPR91 pointing out the succinate as a signal metabolite in hepatic fibrosis [100]. These recent findings clearly indicate a critical tumor-suppressive function for $\mathrm{SDH}$ and highlight its crucial in HCC pathogenesis and metabolic reprogramming.

\subsection{Fumarate Hydratase}

Fumarate hydratase (FH) is encoded by FH gene and exists in cytosolic and mitochondrial forms, differing only in the translation start site used. The mitochondrial enzyme derives from the N-terminal extended form that contain the FH mitochondrial targeting sequence, the removal of which results in the same form as in the cytoplasm. FH catalyzes the reversible conversion of fumarate to L-malate [101]. The mitochondrial form participates in the TCA cycle, whereas the cytosolic FH is involved in different pathways including the urea and the purine nucleotide cycles [102].

FH has been proposed to function as a tumor suppressor. In fact, deficiency of FH induces accumulation of the mitochondrial fumarate which promotes HIF- $1 \alpha$ stabilization by inhibition of the prolyl hydroxylases (PHDs) [103].

PHD inhibition, leading to high levels of HIF1, and consequent activation of oncogenic targets essential for tumorigenesis, increases angiogenesis and glucose metabolism [104].

Interestingly, $\mathrm{FH}$ as well as SDH genetic mutations are associated with a methylator phenotype affecting particularly DNA methylation of promoter regions typically with a transcriptional downregulation of tumor suppressor genes [105]. DNA and histone methylation increase reflects DNA and histone demethylase alterations. Therefore, $\mathrm{FH}$ mutations lead to fumarate accumulation and consequently to TET inhibition resulting in a rise of $5-\mathrm{mC} / 5-\mathrm{HmC}$ ratio. In paraganglioma, this increase is related to a metastasis progression and invasiveness [106], and the DNA CPG island hypermethylation has been associated with a poor prognosis [107]. Therefore, FH deficiency may lead to epigenetic reprogramming in different cancers, as gastrointestinal stromal tumors and renal cancer, characterized by FH mutations.

Moreover, FH is also involved in the response to the nuclear DNA double strand breaks [108] to maintain genomic stability [109]. Consequently, FH inactivation takes part in cancer development by inducing a loss of genome integrity.

Interestingly, in HCC cells with portal vein thrombosis, FH expression was found more than 2-fold decreased and this down-regulation leads HCC cells to become aggressive and able to invade the vessels [110].

\subsection{Malate Dehydrogenase}

Malate dehydrogenase (MDH) is encoded by two different genes: MDH1, encoding the cytosolic enzyme and MDH2 gene encoding the mitochondrial enzyme. Both enzymes are part of the MAS and catalyze the reversible reaction of OAA to malate in the presence of NADH. MDH1 is involved in the oxidation of $\mathrm{NADH}$ to $\mathrm{NAD}^{+}$, which is then used for continuing the glycolysis. MDH2, besides being part of TCA cycle, converts the cytosolic malate-produced by MDH1 and transported across the mitochondrial inner membrane- to OAA with reduction of $\mathrm{NAD}^{+}$to $\mathrm{NADH}$, which is used to mitochondrial electron transport chain.

MDHs are stable as dimers and each subunit contains two domains: the NAD-binding domain, in the amino-terminal half, and the carboxy-terminal domain characterized by amino acids necessary 
for catalysis and substrate binding site. Furthermore, MDH is allosterically regulated by different metabolites. In particular, MDH2 is activated by elevated concentrations of malate, whereas high levels of OAA inhibit this reaction [111,112]. An interesting effect is shown by citrate that functions as an inhibitor of reduction of OAA in malate, but activates $\mathrm{MDH} 2$ when malate and $\mathrm{NAD}^{+}$levels are very high making the enzyme adaptable to metabolic changes [113]. The importance of citrate regulation is also corroborated by the existence of a complex between MDH2 and CS whose kinetic advantage is to channel OAA from MDH2 to CS. In fact, the MDH2 reaction is favorite in direction of reduction of OAA, but the formation of enzyme complex drives OAA to synthesize the citrate [114].

In cancer cells the $\mathrm{NAD}^{+} / \mathrm{NADH}$ homeostasis is maintained by both glycolysis and oxidative phosphorylation. In this scenario, $\mathrm{MDH}$-as part of MAS-represents an important link between these two processes, consequently, MDH induced expression was investigated as malignancy marker [115].

Recently, MDH2 was associated with several type of cancer in which MDH2 expression levels were found increased. Indeed, the regulation of MDH2 activity was proposed as target to mediate resistance cancer cells to chemotherapy [116]. Accordingly, MDH2 inhibition by different compounds causes a decrease of mitochondrial respiration by the reduction of NADH levels and mitochondrial oxygen consumption with an increase of oxygen content which can lead to HIF-1 degradation [117]. Of note, two Oncomine datasets (https://www.oncomine.org/) report MDH2 up-regulation in HCC samples highlighting its role in tumorigenic metabolic reprogramming of liver cells.

\subsection{Citrate/Pyruvate Shuttle}

TCA cycle-derived citrate is exported from mitochondria to the cytosol, through CIC, a member of the mitochondrial carrier family encoded by SLC25A1 gene [22]. In the cytosol, ACLY catalyzes the conversion of citrate and CoA into OAA and acetyl-CoA. The latter is used for fatty acids and sterol biosynthesis, whereas MDH1 reduces OAA to malate, which is then converted to pyruvate via malic enzyme 1 (ME1) thus producing cytosolic NADPH and $\mathrm{H}^{+}$(necessary for fatty acid and sterol synthesis) [118]. First, through the mitochondrial citrate export, citrate/pyruvate shuttle replenishes cytosolic substrates for lipogenesis, very raised in tumors. Thus, CIC plays a key role in regulating the amount of citrate transported. For this reason, SLC25A1 gene is tightly regulated by transcriptional factors and epigenetics in physiological and pathological conditions [119-121]. Of note, both SLC25A1 and ACLY genes are up-regulated via NF-кB in LPS and TNF $\alpha$-activated M1 macrophages [122-124]. Therefore, it could be likely hypothesized a role for NF-KB in SLC25A1 and ACLY up-regulation found in a variety of cancers, including HCC.

Other effects of the citrate/pyruvate shuttle are NADH oxidation-useful for the increased aerobic glycolysis of tumor cells-and NADPH production. Cancer cells can require more NADPH for lipid metabolism, redox homeostasis and molecular biosynthesis than their normal counterparts [125]. By reducing $\mathrm{NADP}^{+}$to NADPH, ME1 has been reported to be a major metabolic enzyme which contributes to the balance of intracellular NADPH for macromolecular biosynthesis and protects from excessive oxidative stress [126].

Indeed, immoderate levels of ROS often found in cancer cells, may damage cellular macromolecules and lead to apoptosis [127]. In this context, citrate/pyruvate shuttle through ME1 enhances NADPH production preserving redox homeostasis (Figure 2). Accordingly, ME1 gene silencing in HCC cell lines induces increased levels of ROS and reduced NADPH [128].

In gastric cancer, ME1 has also a key function in providing NADPH for glutathione and ROS homeostasis, which was critical for cancer cell survival under energy stress conditions, such as glucose limitations. Furthermore, aberrant ME1 gene expression was associated with poor prognosis of gastric cancer. Exploring the therapeutic potential of ME1 in cell line-based as well as patient derived xenograft models, gene silencing of ME1 significantly suppressed tumor growth increasing cell apoptosis [129]. ME1-repressed cells show a decreased tolerance to low-glucose condition and diminished migration and invasion of nasopharyngeal cancer cells [130]. ME1 overexpression also confers radiation resistance in lung cancer [131]. 
About further implications in HCC progression, a recent study reports an ME1 up-regulation in 65 HCC when compared to peritumoral tissues. ME1 gene silencing inhibits migratory and invasive properties of HCC cells. Of note, ME1 overexpression was significantly associated with reduced overall survival and reduced progression-free survival of HCC patients [128].

\subsection{The Malate/Aspartate Shuttle (MAS)}

The maintenance of the REDOX state of cancer cell is crucial for promoting tumor survival and proliferation [132]. In recent years, a large amount of evidence has highlighted the importance of redox homeostasis in cancer cells, including HCC.

A central role in the redox homeostasis is played by the MAS, in which two mitochondrial carriers, the aspartate/glutamate carrier isoform 1 (AGC1), encoded by the SLC25A12 gene and the glutamate/aspartate isoform 2 (AGC2) encoded by the SLC25A13 gene, are involved [133]. They are differently expressed in various tissues: AGC1 is abundant in brain, pancreas, skeletal muscle, but at a very low level in liver, whereas AGC2 is ubiquitous and particularly abundant in liver and kidney [134]. Despite the evidence that the MAS activity increased in hepatoma and leukemia since 1976 [135], only recently the functional importance of the transported metabolites (glutamate and aspartate) and related mitochondrial carriers in HCC has been studied.

AGC1 isoform is significantly upregulated in HCC, whereas AGC2 is downregulated with respect to normal liver cells. FOXA2, a well-known tumor suppressor and a transcriptional regulator of SLC25A13 gene, can be responsible for its high expression levels in liver and its downregulation in HCC [136].

Concerning SLC25A12 gene, an in-depth analysis by using Oncomine and Human Proteome Atlas datasets also showed a strong upregulation in other types of tumors. Epigenetic mechanisms promote SLC25A12 up-regulation in HCC as its expression levels are depend on acetyl-CoA amount. In fact, acetylation of $\mathrm{H} 3$ and $\mathrm{H} 4$ histones as well as CREB binding at SLC25A12 promoter are reduced during ACLY inhibition. Of note, SLC25A12 but not SLC25A13 gene silencing induces a cell cycle arrest in G1 phase of HCC cells [137]. Likely, an epigenetic reprogramming including SLC25A12 control occurs to enable liver cancer cell survival and growth [138,139]. AGC1 plays a dual role: to maintain $\mathrm{NADH} / \mathrm{NAD}^{+}$homeostasis, by providing $\mathrm{NADH}$ to the mitochondria, and to support aspartate needed for the increased metabolic biosynthesis, in particular for the nucleotide synthesis [140,141]. In fact, aspartate as well as deoxynucleotide treatment reverses cell proliferation of SLC25A12-but not SLC25A13-silenced HCC cell lines.

Mitochondrial aspartate export is essential for de novo nucleotide synthesis because of the low aspartate cell permeability [23]. Of note, metabolic and epigenetic reprogramming as well as genetic mutations can compromise the mitochondrial membrane potential of tumor cells [142,143], required for aspartate biosynthesis [144].

Thus, the increased activity of AGC1 is also essential for redox homeostasis by moving NADH to mitochondria, promoting mitochondria energization and in turn mitochondrial aspartate export of HCC cells. A specific function for AGC1 in redox balance of cancer cells has been also pointed up by Amodeo et al. [145]. Therefore, AGC1 function ensures enough aspartate for both redox homeostasis and cell proliferation. Kinetic evidence is in support of this hypothesis. In fact, recombinant AGC1 and AGC2 reconstituted in proteoliposomes show an identical half-saturation constants (Km), but a different Vmax (much lower for AGC1 than that of AGC2) [146].

Hence, although both AGC1 and AGC2 are involved in MAS, AGC1 has a specific role in nucleotide biosynthesis of HCC cells. Accordingly, aspartate derived from several metabolic pathways has been recently identified as a critical intermediate for de novo nucleotide biosynthesis of dividing cells [140]. Of note, aspartate drives cell proliferation in citrullinemia type I (with arginosuccinate synthase deficiency) as well as in tumors showing arginosuccinate synthase down-regulation [147].

The role of AGC1 as cytosolic aspartate supplier was further investigated by Furkan Alkan which demonstrated that AGC1 knockdown slows in vivo growth of mouse lung and pancreas cancer cells, 
reduces cellular $\mathrm{NAD}^{+} / \mathrm{NADH}$ ratio, and impairs aspartate supply to cytosol. Tumor growth was further reduced when in vivo cells were treated with CB-839, a GLS inhibitor, suggesting that loss of AGC1 can synergize with GLS inhibitors. Proliferation was restored upon exogenous aspartate supplementation even when aspartate aminotransferase was blocked suggesting that aspartate is not required to replenish TCA cycle for promoting cell proliferation [148].

When compared to AGC proteins, MDH1 and oxoglutarate mitochondrial carrier (OGC) gene expression—other components of MAS-seem less regulated in cancer cells. Indeed, their expression levels are not chancing in many cancer datasets analyzed (https://www.oncomine.org/), including HCC. Intriguingly, the critical role played by MAS in HCC is ascribable, at least in part, to AGC proteins whose genes are tightly regulated by different molecular mechanisms during liver cell tumorigenesis.

\subsection{Glutamine Metabolism}

Glutamine metabolism is also important in the maintenance of redox state. It is critical during cell growth and proliferation since it can act as precursor in the biosynthesis of different amino acids, proteins, nucleotides, and other molecules. Recently, glutamine has gained attention because its metabolism rapidly changes in cancer cells. Notably, glutamine deprivation is an effective way to suppress cancer cell growth [149].

Through different transport systems for amino acids [150] glutamine cross the plasma membrane. Then, by a still unknown mitochondrial carrier, enters mitochondria where it can be metabolized by an oxidative and/or reductive metabolism [151]. In the presence of oxygen and active respiration, GLS and GDH transform glutamine in $\alpha \mathrm{KG}$, which enters TCA cycle, supporting energy production, and some substrates for other biosynthetic pathways. In the hypoxic conditions $\alpha \mathrm{KG}$ from glutamine may be converted into citrate that is exported from mitochondria into cytosol.

Glutamine also supports the production of glutathione (GSH), the most abundant antioxidant in hepatocytes that helps to prevent oxidative stress in most cells and decreases ROS levels [152]. Through glutaminolysis, glutamine is converted into glutamate, one of the glutathione precursors. In the antioxidant function, the reduced GSH is oxidized to the dimer form GSSG. The GSH/GSSG ratio is a good indicator for redox balance. The regeneration of GSH requires the glutathione reductase enzyme and reducing equivalents in the form of NADPH.

HIF-1 contributes to the tight regulation of glutamine metabolism occurring in cancer cells. This control seems to be one of the causes of carcinogenesis [153]. In addition, GLS up-regulation in cancer is mediated by NF-KB [154].

Concerning HCC, the role of glutamine is not yet clear, because conflicting data have been reported so far. De Waal et al. [155] reported that glutamine is metabolized via oxidative way in HCC whereas Bjornson et al. [156] showed that the transformation of glutamine to $\alpha \mathrm{KG}$ is down-regulated in HCC with respect to the normal cells. Interestingly, Yuneva et al. [13] reported that glutamine metabolism could depend on initiating liver lesion in HCC. Likely, this is due not only to microenvironmental conditions, but also to genetic gene alterations.

\section{TCA Cycle and Related Enzymes as New Potential Therapeutic Targets}

\subsection{Targeting $M D H 2$ and Malic Enzymes}

A first potential anticancer target protein of TCA cycle is MDH2, the mitochondrial isoform of malate dehydrogenase. In prostate cancer cells, $\mathrm{MDH} 2$ overexpression is associated with a shorter survival and a chemoresistance. On the contrary, MDH2 knockdown via shRNA leads to cell proliferation decrease and a chemosensitivity increase [116].

MDH2 was identified as target of LW6, an aryloxyacetylamino benzoic acid analog, potently able to inhibit HIF- $1 \alpha$ accumulation. Indeed, MDH2 inhibition through LW6 leads to TCA cycle and mitochondrial respiration impairment thus increasing oxygen concentration and in turn HIF- $1 \alpha$ 
degradation (Figure 3) [117]. These data underline the potential role of MDH2 inhibition in cancer therapeutics and open the way to new inhibitors.

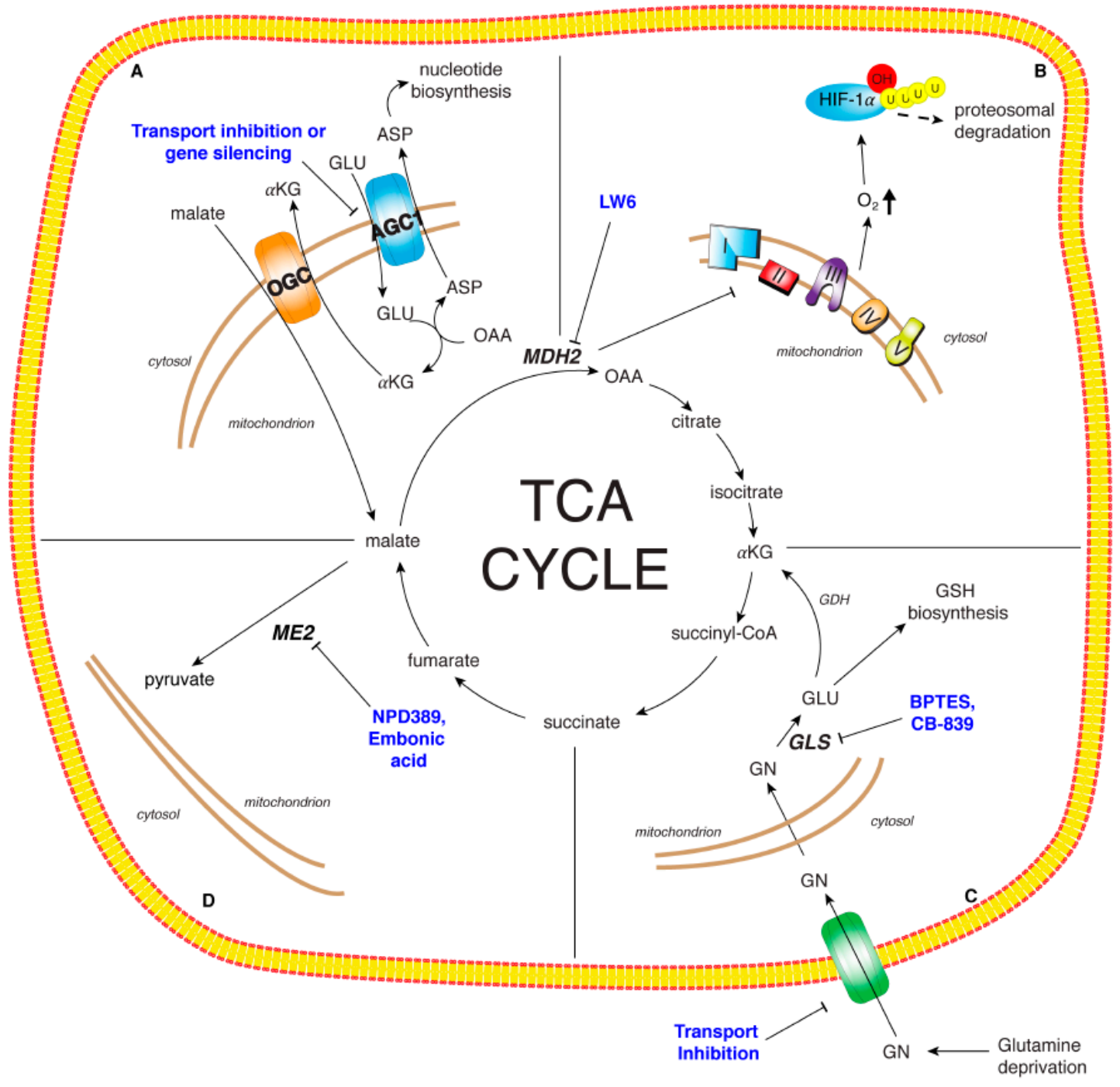

Figure 3. Therapeutic targets of TCA cycle and related enzymes. Panel A: The malate/aspartate shuttle essential for the maintenance of the REDOX state of cancer cell. The specific up-regulation of AGC1 in HCC may by targeted through gene silencing or specific protein transport inhibitors. Panel B: Malate dehydrogenase isoform 2 (MDH2): LW6, an aryloxyacetylamino benzoic acid analog, was identified as $\mathrm{MDH} 2$ inhibitor leading to TCA cycle impairment, mitochondrial respiration decrease and oxygen concentration increase which in turn induces HIF- $1 \alpha$ degradation. Panel C: Glutamine metabolism critical for cancer cell growth and proliferation. The modulation of glutamine metabolism has been proposed via glutamine deprivation, transport inhibition, reduction of glutamine metabolic enzyme activities. BPTES and CB-839 represent two promising inhibitors of GLS. Panel D: Malic enzyme isoform 2 (ME2): NPD389 and embonic acid are non-competitive inhibitors of ME2. ME2 inhibition could impair cancer cell proliferation and growth.

Related to MDH2 inhibition and mitochondrial malate accumulation, another potential anticancer target is malic enzyme isoform 2 (ME2). Three isoforms of malic enzyme have been identified: the cytosolic $\mathrm{NADP}^{+}$-dependent isoform ME1, the mitochondrial NAD $(\mathrm{P})^{+}$-dependent isoform ME2 and the mitochondrial $\mathrm{NADP}^{+}$-dependent isoform ME3. MEs catalyze oxidative decarboxylation of malate to pyruvate and $\mathrm{CO}_{2}$, with the production of NADH or NADPH [157]. ME2 is active in the presence of 
high levels of amino acids and provides mitochondrial pyruvate thus increasing TCA cycle flux in limiting glucose condition [158].

ME2 is considered a potential anticancer target considering his increased activity in cells as Morris hepatomas [159]. Furthermore, it was demonstrated that ME2 knockdown impairs the proliferation and the growth of different cancer cell lines. No inhibitors of human ME2 are currently known, but When et al. have identified, through a high-throughput screening system, NPD389 as a potent non-competitive inhibitor for ME2 [160]. However, the cytotoxic effect of this compound in different cancer cell lines was still not investigated. In vitro ME2 activity inhibition was also investigated with the natural compound embonic acid which also shows a non-competitive inhibition against ME2 and a reduction of growth of H1299 cancer cells (Figure 3). The cytotoxic activity of embonic acid has been evaluated, but the direct involvement of ME2 must still be investigated.

Furthermore, ME1 is used as prognostic and predictive marker for radiotherapy in cancer suggesting a critical role in metabolic reprogramming of cancer cells [128]. Although no ME1 inhibitors are currently being evaluated in clinical trials, a strategy combining ME1 and glycolysis inhibition, would provide an effective therapeutic option for cancer treatment. Since ME1 overexpression is critical for HCC redox homeostasis and is significantly associated with reduced overall survival of HCC patients, ME1 inhibition could be promising even in this malignancy.

\subsection{Targeting $M A S$}

The specific up-regulation of AGC1 in HCC is a very interesting new finding to address new therapeutic targets. Its knockdown strongly decreases HCC cell growth and migration by reducing cytosolic aspartate levels for nucleotide biosynthesis (Figure 3). Thus, inhibiting AGC1 expression leads to a significant reduction of aspartate supply to the cytosol. Different strategies may be employed to reduce AGC1 expression.

Since its overexpression is due to epigenetic regulation, using epigenetic modifier could be tested. It is widely demonstrated that epigenetic alterations are associated with different mechanisms of proliferation and metastasis in several types of cancer, including HCC [139,161-163]. Histone acetylation is one of most important epigenetic mechanisms, regulating cellular events such as differentiation, proliferation, and cell cycle. Deregulated histone acetyltransferases and histone deacetyltransferase activity plays a role in the development of a range of cancers. Of note, histone acetylase coactivator p300 contributes to the development of hepatic steatosis via histone and non-histone acetylation [164]. It has also been found p300 high expression in HCC. In addition, p300 overexpression is a biomarker for poor prognosis of HCC patients [165]. Consequently, inhibitors of these epigenetic enzymes have potential as anticancer agents.

Beyond repression at transcriptional level, inhibition of transport activity could be another strategy (Figure 3). Currently, specific AGC1 inhibitors are not available; however, they could be found among the best binders of a virtual screening as well as among those small molecules in the ligand-clusters containing the AGC reference substrates and the traditional mitochondrial carrier inhibitors $[146,166]$.

\subsection{Targeting Glutamine}

In recent years glutamine metabolism has become a very interesting topic target in cancer therapy. Glutamine metabolism can be modulated through deprivation, uptake restriction, usage of glutamine analogs, glutaminolysis inhibition, and metabolic regulators of cancer cells. Although these strategies have been tested in different types of cancer other than HCC, their efficacy in this malignancy is not excluded.

There are multiple effects of glutamine deprivation in cancers including apoptosis and autophagy induction, increase of mitochondrial ROS, decrease of GSH levels [167], and cell cycle arrest [168].

Another strategy to affect glutamine metabolism concerns the transport inhibition (Figure 3). Some transport systems for amino acids to cross plasma membrane, such as $\mathrm{Na}^{+}$-dependent system $\mathrm{A}$, $\mathrm{Na}^{+}$-dependent system $\mathrm{N}, \mathrm{Na}^{+}$-dependent system ASC (alanine serine cystein) and $\mathrm{Na}^{+}$-independent 
system L are used for glutamine transport. Two of them, ASCT2 and LAT1 up-regulated in cancer [150], have been tested for glutamine transport inhibition. ASCT2 inhibition decreases glutamine uptake and cell cycle progression [169]. Inhibition of LAT1 leads to a reduction of cell proliferation and viability of different cancer cells [170]. Furthermore, another target can be the liver receptor homolog (LRH-1), implicated in coordinating glutamine-induced metabolism and hepatocarcinogenesis. Xu et al. demonstrated that LRH-1 deletion inhibited HCC cell proliferation through different mechanism, such as reduction of glutamine deamination and glutaminolysis and inhibition of mTOR signaling [171].

The most promising therapeutic target so far is the inhibition of GLS by the allosteric GLS-selective inhibitor, bis-2-(5-phenylacetamido-1,3,4-thiadiazol-2-yl)ethyl sulfide (BPTES) and BPTES like-drug CB-839 (Figure 3). BPTES shows an antitumor effect in different tumor types, and a prolonged survival in a model of murine hepatocellular carcinoma without toxic side effects [154]. Considering the moderate effect together with the poor metabolic stability and the low solubility, a new potent allosteric inhibitor of GLS, CB-839, was clinically tested. Moreover, CB-839 affects TCA cycle reprogramming, glutathione production and amino acids synthesis [172]. Thus, this compound is in Phase I clinical trials for treatment of hematological and solid tumors (NCT02071927 and NCT02071888). Considering previous findings, it could also be supposed to have beneficial effects in HCC.

\section{Conclusions}

Metabolic pathway alterations characterize HCC resulting in a global metabolic reprogramming. Among them, significant changes in TCA cycle and related enzymes correlate with cancer cell transformation and progression. The maintenance of the REDOX state is also crucial for promoting tumor survival and proliferation. In this review, following an updated analysis of TCA cycle, related shuttles, and glutamine fate in HCC, we propose that targeting these pathways might have significant clinical implications and open new windows in the therapeutic strategies. However, incoming studies need to deepen our understanding of TCA cycle rewiring in HCC and better develop therapeutic tools for this malignancy.

Author Contributions: V.I. (Vittoria Infantino) and V.I. (Vito Iacobazzi) conceived the review; V.I. (Vito Iacobazzi), S.T., V.I. (Vittoria Infantino) and P.C. wrote the paper, V.I. (Vito Iacobazzi), S.T., V.I. (Vittoria Infantino) and P.C. critically revised the final version of the manuscript. All authors have read and agreed to the published version of the manuscript.

Funding: This research was supported by grants from University of Basilicata and University of Bari.

Conflicts of Interest: The authors declare no conflict of interest.

\section{References}

1. Mazzanti, R.; Gramantieri, L.; Bolondi, L. Hepatocellular carcinoma: Epidemiology and clinical aspects. Mol. Asp. Med. 2008, 29, 130-143. [CrossRef] [PubMed]

2. Cornella, H.; Alsinet, C.; Villanueva, A. Molecular pathogenesis of hepatocellular carcinoma. Alcohol. Clin. Exp. Res. 2011, 35, 821-825. [CrossRef] [PubMed]

3. Llovet, J.M.; Di Bisceglie, A.M.; Bruix, J.; Kramer, B.S.; Lencioni, R.; Zhu, A.X.; Sherman, M.; Schwartz, M.; Lotze, M.; Talwalkar, J.; et al. Design and endpoints of clinical trials in hepatocellular carcinoma. J. Natl. Cancer Inst. 2008, 100, 698-711. [CrossRef] [PubMed]

4. Bruix, J.; Sherman, M. Management of hepatocellular carcinoma. Hepatology 2005, 42, 1208-1236. [CrossRef]

5. Hanahan, D.; Weinberg, R.A. Hallmarks of cancer: The next generation. Cell 2011, 144, 646-674. [CrossRef]

6. Warburg, O.; Wind, F.; Negelein, E. The metabolism of tumors in the body. J. Gen. Physiol. 1927, 8, 519-530. [CrossRef]

7. Almuhaideb, A.; Papathanasiou, N.; Bomanji, J. 18f-fdg pet/ct imaging in oncology. Ann. Saudi Med. 2011, 31, 3-13. [CrossRef]

8. Pavlova, N.N.; Thompson, C.B. The emerging hallmarks of cancer metabolism. Cell Metab. 2016, 23, 27-47. [CrossRef]

9. Warburg, O. On the origin of cancer cells. Science 1956, 123, 309-314. [CrossRef] 
10. Tan, A.S.; Baty, J.W.; Dong, L.F.; Bezawork-Geleta, A.; Endaya, B.; Goodwin, J.; Bajzikova, M.; Kovarova, J.; Peterka, M.; Yan, B.; et al. Mitochondrial genome acquisition restores respiratory function and tumorigenic potential of cancer cells without mitochondrial DNA. Cell Metab. 2015, 21, 81-94. [CrossRef]

11. Eagle, $\mathrm{H}$. The minimum vitamin requirements of the 1 and hela cells in tissue culture, the production of specific vitamin deficiencies, and their cure. J. Exp. Med. 1955, 102, 595-600. [CrossRef] [PubMed]

12. Rivera, S.; Azcon-Bieto, J.; Lopez-Soriano, F.J.; Miralpeix, M.; Argiles, J.M. Amino acid metabolism in tumour-bearing mice. Biochem. J. 1988, 249, 443-449. [CrossRef] [PubMed]

13. Yuneva, M.O.; Fan, T.W.; Allen, T.D.; Higashi, R.M.; Ferraris, D.V.; Tsukamoto, T.; Mates, J.M.; Alonso, F.J.; Wang, C.; Seo, Y.; et al. The metabolic profile of tumors depends on both the responsible genetic lesion and tissue type. Cell Metab. 2012, 15, 157-170. [CrossRef] [PubMed]

14. Venneti, S.; Dunphy, M.P.; Zhang, H.; Pitter, K.L.; Zanzonico, P.; Campos, C.; Carlin, S.D.; La Rocca, G.; Lyashchenko, S.; Ploessl, K.; et al. Glutamine-based pet imaging facilitates enhanced metabolic evaluation of gliomas in vivo. Sci. Transl. Med. 2015, 7, 274ra17. [CrossRef]

15. DeBerardinis, R.J.; Mancuso, A.; Daikhin, E.; Nissim, I.; Yudkoff, M.; Wehrli, S.; Thompson, C.B. Beyond aerobic glycolysis: Transformed cells can engage in glutamine metabolism that exceeds the requirement for protein and nucleotide synthesis. Proc. Natl. Acad. Sci. USA 2007, 104, 19345-19350. [CrossRef]

16. Metallo, C.M.; Gameiro, P.A.; Bell, E.L.; Mattaini, K.R.; Yang, J.; Hiller, K.; Jewell, C.M.; Johnson, Z.R.; Irvine, D.J.; Guarente, L.; et al. Reductive glutamine metabolism by idh1 mediates lipogenesis under hypoxia. Nature 2011, 481, 380-384. [CrossRef]

17. Menendez, J.A.; Lupu, R. Fatty acid synthase and the lipogenic phenotype in cancer pathogenesis. Nat. Rev. Cancer 2007, 7, 763-777. [CrossRef]

18. Rysman, E.; Brusselmans, K.; Scheys, K.; Timmermans, L.; Derua, R.; Munck, S.; Van Veldhoven, P.P.; Waltregny, D.; Daniels, V.W.; Machiels, J.; et al. De novo lipogenesis protects cancer cells from free radicals and chemotherapeutics by promoting membrane lipid saturation. Cancer Res. 2010, 70, 8117-8126. [CrossRef]

19. Kaplan, R.S.; Morris, H.P.; Coleman, P.S. Kinetic characteristics of citrate influx and efflux with mitochondria from morris hepatomas 3924a and 16. Cancer Res. 1982, 42, 4399-4407.

20. Catalina-Rodriguez, O.; Kolukula, V.K.; Tomita, Y.; Preet, A.; Palmieri, F.; Wellstein, A.; Byers, S.; Giaccia, A.J.; Glasgow, E.; Albanese, C.; et al. The mitochondrial citrate transporter, cic, is essential for mitochondrial homeostasis. Oncotarget 2012, 3, 1220-1235. [CrossRef]

21. Pope, E.D., 3rd; Kimbrough, E.O.; Vemireddy, L.P.; Surapaneni, P.K.; Copland, J.A., 3rd; Mody, K. Aberrant lipid metabolism as a therapeutic target in liver cancer. Expert Opin. Ther. Targets 2019, 23, 473-483. [CrossRef] [PubMed]

22. Palmieri, F. The mitochondrial transporter family (slc25): Physiological and pathological implications. Pflug. Arch. Eur. J. Physiol. 2004, 447, 689-709. [CrossRef] [PubMed]

23. Sullivan, L.B.; Luengo, A.; Danai, L.V.; Bush, L.N.; Diehl, F.F.; Hosios, A.M.; Lau, A.N.; Elmiligy, S.; Malstrom, S.; Lewis, C.A.; et al. Aspartate is an endogenous metabolic limitation for tumour growth. Nat. Cell Biol. 2018, 20, 782-788. [CrossRef] [PubMed]

24. Tannahill, G.M.; Curtis, A.M.; Adamik, J.; Palsson-McDermott, E.M.; McGettrick, A.F.; Goel, G.; Frezza, C.; Bernard, N.J.; Kelly, B.; Foley, N.H.; et al. Succinate is an inflammatory signal that induces il-1beta through HIF-1alpha. Nature 2013, 496, 238-242. [CrossRef]

25. Myllyla, R.; Tuderman, L.; Kivirikko, K.I. Mechanism of the prolyl hydroxylase reaction. 2. Kinetic analysis of the reaction sequence. Eur. J. Biochem. 1977, 80,349-357. [CrossRef]

26. Selak, M.A.; Armour, S.M.; MacKenzie, E.D.; Boulahbel, H.; Watson, D.G.; Mansfield, K.D.; Pan, Y.; Simon, M.C.; Thompson, C.B.; Gottlieb, E. Succinate links tca cycle dysfunction to oncogenesis by inhibiting HIF- $\alpha$ prolyl hydroxylase. Cancer Cell 2005, 7, 77-85. [CrossRef]

27. Karin, M. NF-кB as a critical link between inflammation and cancer. Cold Spring Harb. Perspect. Biol. 2009, 1, a000141. [CrossRef]

28. Merle, P.; Trepo, C. Molecular mechanisms underlying hepatocellular carcinoma. Viruses 2009, 1, 852-872. [CrossRef]

29. Qian, B.Z.; Pollard, J.W. Macrophage diversity enhances tumor progression and metastasis. Cell 2010, 141, 39-51. [CrossRef]

30. Grivennikov, S.I.; Greten, F.R.; Karin, M. Immunity, inflammation, and cancer. Cell 2010, 140, 883-899. [CrossRef] 
31. Pollard, J.W. Tumour-educated macrophages promote tumour progression and metastasis. Nat. Rev. Cancer 2004, 4, 71-78. [CrossRef] [PubMed]

32. Dolcet, X.; Llobet, D.; Pallares, J.; Matias-Guiu, X. NF-кB in development and progression of human cancer. Virchows Arch. Int. J. Pathol. 2005, 446, 475-482. [CrossRef] [PubMed]

33. Gilmore, T.D. Multiple mutations contribute to the oncogenicity of the retroviral oncoprotein v-rel. Oncogene 1999, 18, 6925-6937. [CrossRef] [PubMed]

34. Cabannes, E.; Khan, G.; Aillet, F.; Jarrett, R.F.; Hay, R.T. Mutations in the ikba gene in hodgkin's disease suggest a tumour suppressor role for IKB $\alpha$. Oncogene 1999, 18, 3063-3070. [CrossRef]

35. Migliazza, A.; Lombardi, L.; Rocchi, M.; Trecca, D.; Chang, C.C.; Antonacci, R.; Fracchiolla, N.S.; Ciana, P.; Maiolo, A.T.; Neri, A. Heterogeneous chromosomal aberrations generate 3' truncations of the nfkb2/lyt-10 gene in lymphoid malignancies. Blood 1994, 84, 3850-3860. [CrossRef]

36. Houldsworth, J.; Mathew, S.; Rao, P.H.; Dyomina, K.; Louie, D.C.; Parsa, N.; Offit, K.; Chaganti, R.S. Rel proto-oncogene is frequently amplified in extranodal diffuse large cell lymphoma. Blood 1996, 87, 25-29. [CrossRef]

37. Mukhopadhyay, T.; Roth, J.A.; Maxwell, S.A. Altered expression of the p50 subunit of the NF- $\mathrm{kB}$ transcription factor complex in non-small cell lung carcinoma. Oncogene 1995, 11, 999-1003.

38. Romieu-Mourez, R.; Kim, D.W.; Shin, S.M.; Demicco, E.G.; Landesman-Bollag, E.; Seldin, D.C.; Cardiff, R.D.; Sonenshein, G.E. Mouse mammary tumor virus c-rel transgenic mice develop mammary tumors. Mol. Cell. Biol. 2003, 23, 5738-5754. [CrossRef]

39. Nair, A.; Venkatraman, M.; Maliekal, T.T.; Nair, B.; Karunagaran, D. NF-кB is constitutively activated in high-grade squamous intraepithelial lesions and squamous cell carcinomas of the human uterine cervix. Oncogene 2003, 22, 50-58. [CrossRef]

40. Sasaki, N.; Morisaki, T.; Hashizume, K.; Yao, T.; Tsuneyoshi, M.; Noshiro, H.; Nakamura, K.; Yamanaka, T.; Uchiyama, A.; Tanaka, M.; et al. Nuclear factor-kappab p65 (rela) transcription factor is constitutively activated in human gastric carcinoma tissue. Clin. Cancer Res. Off. J. Am. Assoc. Cancer Res. 2001, 7, 4136-4142.

41. Elsharkawy, A.M.; Mann, D.A. Nuclear factor-kappab and the hepatic inflammation-fibrosis-cancer axis. Hepatology 2007, 46, 590-597. [CrossRef] [PubMed]

42. Mollica, M.P.; Lionetti, L.; Putti, R.; Cavaliere, G.; Gaita, M.; Barletta, A. From chronic overfeeding to hepatic injury: Role of endoplasmic reticulum stress and inflammation. Nutr. Metab. Cardiovasc. Dis. Nmcd 2011, 21, 222-230. [CrossRef] [PubMed]

43. Forbes, S.J.; Parola, M. Liver fibrogenic cells. Best Pract. Res. Clin. Gastroenterol. 2011, 25, 207-217. [CrossRef] [PubMed]

44. Racanelli, V.; Rehermann, B. The liver as an immunological organ. Hepatology 2006, 43, S54-S62. [CrossRef] [PubMed]

45. Thirunavukkarasu, C.; Watkins, S.C.; Gandhi, C.R. Mechanisms of endotoxin-induced NO, IL-6, and TNF- $\alpha$ production in activated rat hepatic stellate cells: Role of p38 mapk. Hepatology 2006, 44, 389-398. [CrossRef] [PubMed]

46. Cani, P.D.; Bibiloni, R.; Knauf, C.; Waget, A.; Neyrinck, A.M.; Delzenne, N.M.; Burcelin, R. Changes in gut microbiota control metabolic endotoxemia-induced inflammation in high-fat diet-induced obesity and diabetes in mice. Diabetes 2008, 57, 1470-1481. [CrossRef] [PubMed]

47. Cai, D.; Yuan, M.; Frantz, D.F.; Melendez, P.A.; Hansen, L.; Lee, J.; Shoelson, S.E. Local and systemic insulin resistance resulting from hepatic activation of ikk-beta and NF-kB. Nat. Med. 2005, 11, 183-190. [CrossRef]

48. Tan, C.E.; Wang, K.W.; Chew, L.S.; Rajasoorya, C.; Lim, H.S. Manifestations and outcome of treatment of thyrotoxicosis: A clinical study. Ann. Acad. Med. Singap. 1990, 19, 798-801.

49. Johnson, R.F.; Perkins, N.D. Nuclear factor-kappab, p53, and mitochondria: Regulation of cellular metabolism and the warburg effect. Trends Biochem. Sci. 2012, 37, 317-324. [CrossRef]

50. Koong, A.C.; Chen, E.Y.; Giaccia, A.J. Hypoxia causes the activation of nuclear factor kappa $b$ through the phosphorylation of IкB $\alpha$ on tyrosine residues. Cancer Res. 1994, 54, 1425-1430.

51. Van Uden, P.; Kenneth, N.S.; Rocha, S. Regulation of hypoxia-inducible factor- $1 \alpha$ by NF-кB. Biochem J. 2008, 412, 477-484. [CrossRef] [PubMed]

52. Kawauchi, K.; Araki, K.; Tobiume, K.; Tanaka, N. P53 regulates glucose metabolism through an IKK-NF-kB pathway and inhibits cell transformation. Nat. Cell Biol. 2008, 10, 611-618. [CrossRef] [PubMed] 
53. Zhou, F.; Xu, X.; Wu, J.; Wang, D.; Wang, J. NF-kB controls four genes encoding core enzymes of tricarboxylic acid cycle. Gene 2017, 621, 12-20. [CrossRef] [PubMed]

54. Fitzpatrick, S.F. Immunometabolism and sepsis: A role for hif? Front. Mol. Biosci. 2019, 6, 85. [CrossRef]

55. Lisy, K.; Peet, D.J. Turn me on: Regulating hif transcriptional activity. Cell Death Differ. 2008, 15, 642-649. [CrossRef] [PubMed]

56. Gordan, J.D.; Simon, M.C. Hypoxia-inducible factors: Central regulators of the tumor phenotype. Curr. Opin. Genet. Dev. 2007, 17, 71-77. [CrossRef]

57. McKeown, S.R. Defining normoxia, physoxia and hypoxia in tumours-implications for treatment response. Br. J. Radiol. 2014, 87, 20130676. [CrossRef]

58. Semenza, G.L. Hypoxia-inducible factors in physiology and medicine. Cell 2012, 148, 399-408. [CrossRef]

59. Kim, J.W.; Tchernyshyov, I.; Semenza, G.L.; Dang, C.V. Hif-1-mediated expression of pyruvate dehydrogenase kinase: A metabolic switch required for cellular adaptation to hypoxia. Cell Metab. 2006, 3, 177-185. [CrossRef]

60. McFate, T.; Mohyeldin, A.; Lu, H.; Thakar, J.; Henriques, J.; Halim, N.D.; Wu, H.; Schell, M.J.; Tsang, T.M.; Teahan, O.; et al. Pyruvate dehydrogenase complex activity controls metabolic and malignant phenotype in cancer cells. J. Biol. Chem. 2008, 283, 22700-22708. [CrossRef]

61. Zhong, H.; Chiles, K.; Feldser, D.; Laughner, E.; Hanrahan, C.; Georgescu, M.M.; Simons, J.W.; Semenza, G.L. Modulation of hypoxia-inducible factor 1alpha expression by the epidermal growth factor/phosphatidylinositol 3-kinase/pten/akt/frap pathway in human prostate cancer cells: Implications for tumor angiogenesis and therapeutics. Cancer Res. 2000, 60, 1541-1545. [PubMed]

62. Dai, C.X.; Gao, Q.; Qiu, S.J.; Ju, M.J.; Cai, M.Y.; Xu, Y.F.; Zhou, J.; Zhang, B.H.; Fan, J. Hypoxia-inducible factor-1 alpha, in association with inflammation, angiogenesis and myc, is a critical prognostic factor in patients with hcc after surgery. BMC Cancer 2009, 9, 418. [CrossRef] [PubMed]

63. Xiang, Z.L.; Zeng, Z.C.; Fan, J.; Tang, Z.Y.; He, J.; Zeng, H.Y.; Chang, J.Y. The expression of hif-1alpha in primary hepatocellular carcinoma and its correlation with radiotherapy response and clinical outcome. Mol. Biol. Rep. 2012, 39, 2021-2029. [CrossRef] [PubMed]

64. Guaragnella, N.; Giannattasio, S.; Moro, L. Mitochondrial dysfunction in cancer chemoresistance. Biochem. Pharmacol. 2014, 92, 62-72. [CrossRef]

65. Hamaguchi, T.; Iizuka, N.; Tsunedomi, R.; Hamamoto, Y.; Miyamoto, T.; Iida, M.; Tokuhisa, Y.; Sakamoto, K.; Takashima, M.; Tamesa, T.; et al. Glycolysis module activated by hypoxia-inducible factor 1alpha is related to the aggressive phenotype of hepatocellular carcinoma. Int. J. Oncol. 2008, 33, 725-731.

66. Wiegand, G.; Remington, S.J. Citrate synthase: Structure, control, and mechanism. Annu. Rev. Biophys. Biophys. Chem. 1986, 15, 97-117. [CrossRef]

67. Chen, L.; Liu, T.; Zhou, J.; Wang, Y.; Wang, X.; Di, W.; Zhang, S. Citrate synthase expression affects tumor phenotype and drug resistance in human ovarian carcinoma. PLoS ONE 2014, 9, e115708. [CrossRef]

68. Schlichtholz, B.; Turyn, J.; Goyke, E.; Biernacki, M.; Jaskiewicz, K.; Sledzinski, Z.; Swierczynski, J. Enhanced citrate synthase activity in human pancreatic cancer. Pancreas 2005, 30, 99-104. [CrossRef]

69. El-Ashmawy, N.E.; El-Bahrawy, H.A.; Shamloula, M.M.; El-Feky, O.A. Biochemical/metabolic changes associated with hepatocellular carcinoma development in mice. Tumour Biol. J. Int. Soc. Oncodev. Biol. Med. 2014, 35, 5459-5466. [CrossRef]

70. Zhang, J.; Baddoo, M.; Han, C.; Strong, M.J.; Cvitanovic, J.; Moroz, K.; Dash, S.; Flemington, E.K.; Wu, T. Gene network analysis reveals a novel 22-gene signature of carbon metabolism in hepatocellular carcinoma. Oncotarget 2016, 7, 49232-49245. [CrossRef]

71. Gao, R.; Cheng, J.; Fan, C.; Shi, X.; Cao, Y.; Sun, B.; Ding, H.; Hu, C.; Dong, F.; Yan, X. Serum metabolomics to identify the liver disease-specific biomarkers for the progression of hepatitis to hepatocellular carcinoma. Sci. Rep. 2015, 5, 18175. [CrossRef] [PubMed]

72. Stoddard, B.L.; Dean, A.; Koshland, D.E. Structure of isocitrate dehydrogenase with isocitrate, nicotinamide adenine dinucleotide phosphate, and calcium at 2.5-a resolution: A pseudo-michaelis ternary complex. Biochemistry 1993, 32, 9310-9316. [CrossRef] [PubMed]

73. Xu, X.; Zhao, J.; Xu, Z.; Peng, B.; Huang, Q.; Arnold, E.; Ding, J. Structures of human cytosolic nadp-dependent isocitrate dehydrogenase reveal a novel self-regulatory mechanism of activity. J. Biol. Chem. 2004, 279, 33946-33957. [CrossRef] [PubMed] 
74. Ramachandran, N.; Colman, R.F. Chemical characterization of distinct subunits of pig heart dpn-specific isocitrate dehydrogenase. J. Biol. Chem. 1980, 255, 8859-8864. [PubMed]

75. Anderson, N.M.; Mucka, P.; Kern, J.G.; Feng, H. The emerging role and targetability of the tca cycle in cancer metabolism. Protein Cell 2018, 9, 216-237. [CrossRef]

76. Yen, K.E.; Bittinger, M.A.; Su, S.M.; Fantin, V.R. Cancer-associated idh mutations: Biomarker and therapeutic opportunities. Oncogene 2010, 29, 6409-6417. [CrossRef]

77. Zhao, Y.; Zhang, L.; Zhang, Y.; Meng, B.; Ying, W.; Qian, X. Identification of hedgehog signaling as a potential oncogenic driver in an aggressive subclass of human hepatocellular carcinoma: A reanalysis of the tcga cohort. Sci. China Life Sci. 2019, 62, 1481-1491. [CrossRef]

78. Xu, W.; Yang, H.; Liu, Y.; Yang, Y.; Wang, P.; Kim, S.H.; Ito, S.; Yang, C.; Wang, P.; Xiao, M.T.; et al. Oncometabolite 2-hydroxyglutarate is a competitive inhibitor of alpha-ketoglutarate-dependent dioxygenases. Cancer Cell 2011, 19, 17-30. [CrossRef]

79. Cervello, M.; Bachvarov, D.; Lampiasi, N.; Cusimano, A.; Azzolina, A.; McCubrey, J.A.; Montalto, G. Novel combination of sorafenib and celecoxib provides synergistic anti-proliferative and pro-apoptotic effects in human liver cancer cells. PLoS ONE 2013, 8, e65569. [CrossRef]

80. Laurenti, G.; Tennant, D.A. Isocitrate dehydrogenase (idh), succinate dehydrogenase (sdh), fumarate hydratase (fh): Three players for one phenotype in cancer? Biochem. Soc. Trans. 2016, 44, 1111-1116. [CrossRef]

81. Lee, S.M.; Koh, H.J.; Park, D.C.; Song, B.J.; Huh, T.L.; Park, J.W. Cytosolic nadp(+)-dependent isocitrate dehydrogenase status modulates oxidative damage to cells. Free Radic. Biol. Med. 2002, 32, 1185-1196. [CrossRef]

82. Wagenknecht, T.; Francis, N.; DeRosier, D.J. Alpha-ketoglutarate dehydrogenase complex may be heterogeneous in quaternary structure. J. Mol. Biol. 1983, 165, 523-539. [CrossRef]

83. Sheu, K.F.; Blass, J.P. The alpha-ketoglutarate dehydrogenase complex. Ann. N. Y. Acad. Sci. 1999, 893, 61-78. [CrossRef] [PubMed]

84. Lawlis, V.B.; Roche, T.E. Regulation of bovine kidney alpha-ketoglutarate dehydrogenase complex by calcium ion and adenine nucleotides. Effects on s0.5 for alpha-ketoglutarate. Biochemistry 1981, 20, 2512-2518. [CrossRef] [PubMed]

85. McCormack, J.G.; Denton, R.M. The effects of calcium ions and adenine nucleotides on the activity of pig heart 2-oxoglutarate dehydrogenase complex. Biochem J. 1979, 180, 533-544. [CrossRef] [PubMed]

86. Hamada, M.; Koike, K.; Nakaula, Y.; Hiraoka, T.; Koike, M. A kinetic study of the alpha-keto acid dehydrogenase complexes from pig heart mitochondria. J. Biochem. 1975, 77, 1047-1056. [CrossRef] [PubMed]

87. Kiselevsky, Y.V.; Ostrovtsova, S.A.; Strumilo, S.A. Kinetic characterization of the pyruvate and oxoglutarate dehydrogenase complexes from human heart. Acta Biochim. Pol. 1990, 37, 135-139.

88. Schoolwerth, A.C.; LaNoue, K.F. Control of ammoniagenesis by alpha-ketoglutarate in rat kidney mitochondria. Am. J. Physiol. 1983, 244, F399-F408. [CrossRef]

89. Burr, S.P.; Costa, A.S.; Grice, G.L.; Timms, R.T.; Lobb, I.T.; Freisinger, P.; Dodd, R.B.; Dougan, G.; Lehner, P.J.; Frezza, C.; et al. Mitochondrial protein lipoylation and the 2-oxoglutarate dehydrogenase complex controls hif1alpha stability in aerobic conditions. Cell Metab 2016, 24, 740-752. [CrossRef]

90. Vatrinet, R.; Leone, G.; De Luise, M.; Girolimetti, G.; Vidone, M.; Gasparre, G.; Porcelli, A.M. The alphaketoglutarate dehydrogenase complex in cancer metabolic plasticity. Cancer Metab. 2017, 5, 3. [CrossRef]

91. Oldham, W.M.; Clish, C.B.; Yang, Y.; Loscalzo, J. Hypoxia-mediated increases in 1-2-hydroxyglutarate coordinate the metabolic response to reductive stress. Cell Metab. 2015, 22, 291-303. [CrossRef] [PubMed]

92. Wang, Y.; Guo, Y.R.; Liu, K.; Yin, Z.; Liu, R.; Xia, Y.; Tan, L.; Yang, P.; Lee, J.H.; Li, X.J.; et al. Kat2a coupled with the alpha-kgdh complex acts as a histone h3 succinyltransferase. Nature 2017, 552, 273-277. [CrossRef] [PubMed]

93. Rasheed, M.; Tarjan, G. Succinate dehydrogenase complex: An updated review. Arch. Pathol. Lab. Med. 2018, 142, 1564-1570. [CrossRef] [PubMed]

94. Baysal, B.E.; Ferrell, R.E.; Willett-Brozick, J.E.; Lawrence, E.C.; Myssiorek, D.; Bosch, A.; van der Mey, A.; Taschner, P.E.; Rubinstein, W.S.; Myers, E.N.; et al. Mutations in sdhd, a mitochondrial complex ii gene, in hereditary paraganglioma. Science 2000, 287, 848-851. [CrossRef]

95. Gottlieb, E.; Tomlinson, I.P. Mitochondrial tumour suppressors: A genetic and biochemical update. Nat. Rev. Cancer 2005, 5, 857-866. [CrossRef] 
96. Bardella, C.; Pollard, P.J.; Tomlinson, I. Sdh mutations in cancer. Biochim. Biophys. Acta 2011, 1807, 1432-1443. [CrossRef]

97. Shimizu, T.; Inoue, K.; Hachiya, H.; Shibuya, N.; Shimoda, M.; Kubota, K. Frequent alteration of the protein synthesis of enzymes for glucose metabolism in hepatocellular carcinomas. J. Gastroenterol. 2014, 49, 1324-1332. [CrossRef]

98. Tseng, P.L.; Wu, W.H.; Hu, T.H.; Chen, C.W.; Cheng, H.C.; Li, C.F.; Tsai, W.H.; Tsai, H.J.; Hsieh, M.C.; Chuang, J.H.; et al. Decreased succinate dehydrogenase $b$ in human hepatocellular carcinoma accelerates tumor malignancy by inducing the warburg effect. Sci. Rep. 2018, 8, 3081. [CrossRef]

99. Li, J.; Liang, N.; Long, X.; Zhao, J.; Yang, J.; Du, X.; Yang, T.; Yuan, P.; Huang, X.; Zhang, J.; et al. Sdhc-related deficiency of sdh complex activity promotes growth and metastasis of hepatocellular carcinoma via ros/nfkappab signaling. Cancer Lett. 2019, 461, 44-55. [CrossRef]

100. Cho, E.H. Succinate as a regulator of hepatic stellate cells in liver fibrosis. Front. Endocrinol. 2018, 9, 455. [CrossRef]

101. Mann, P.J.; Woolf, B. The action of salts on fumarase. I. Biochem J. 1930, 24, 427-434. [CrossRef] [PubMed]

102. Stepinski, J.; Bizon, D.; Piec, G.; Angielski, S. The purine nucleotide cycle activity in renal cortex and medulla. Am. J. Kidney Dis. Off. J. Natl. Kidney Found. 1989, 14, 307-309. [CrossRef]

103. Isaacs, J.S.; Jung, Y.J.; Mole, D.R.; Lee, S.; Torres-Cabala, C.; Chung, Y.L.; Merino, M.; Trepel, J.; Zbar, B.; Toro, J.; et al. Hif overexpression correlates with biallelic loss of fumarate hydratase in renal cancer: Novel role of fumarate in regulation of hif stability. Cancer Cell 2005, 8, 143-153. [CrossRef] [PubMed]

104. Pollard, P.J.; Briere, J.J.; Alam, N.A.; Barwell, J.; Barclay, E.; Wortham, N.C.; Hunt, T.; Mitchell, M.; Olpin, S.; Moat, S.J.; et al. Accumulation of krebs cycle intermediates and over-expression of hif1alpha in tumours which result from germline fh and sdh mutations. Hum. Mol. Genet. 2005, 14, 2231-2239. [CrossRef] [PubMed]

105. Jones, P.A.; Baylin, S.B. The epigenomics of cancer. Cell 2007, 128, 683-692. [CrossRef] [PubMed]

106. Wong, C.C.; Qian, Y.; Yu, J. Interplay between epigenetics and metabolism in oncogenesis: Mechanisms and therapeutic approaches. Oncogene 2017, 36, 3359-3374. [CrossRef]

107. Letouze, E.; Martinelli, C.; Loriot, C.; Burnichon, N.; Abermil, N.; Ottolenghi, C.; Janin, M.; Menara, M.; Nguyen, A.T.; Benit, P.; et al. Sdh mutations establish a hypermethylator phenotype in paraganglioma. Cancer Cell 2013, 23, 739-752. [CrossRef]

108. Leshets, M.; Silas, Y.B.H.; Lehming, N.; Pines, O. Fumarase: From the tca cycle to DNA damage response and tumor suppression. Front. Mol. Biosci. 2018, 5, 68. [CrossRef]

109. Yogev, O.; Yogev, O.; Singer, E.; Shaulian, E.; Goldberg, M.; Fox, T.D.; Pines, O. Fumarase: A mitochondrial metabolic enzyme and a cytosolic/nuclear component of the DNA damage response. PLoS Biol. 2010, 8, e1000328. [CrossRef]

110. Lee, W.C.; Chou, H.S.; Wu, T.J.; Lee, C.F.; Hsu, P.Y.; Hsu, H.Y.; Wu, T.H.; Chan, K.M. Down-regulation of metabolic proteins in hepatocellular carcinoma with portal vein thrombosis. Clin. Proteom. 2017, 14, 29. [CrossRef]

111. Mullinax, T.R.; Mock, J.N.; McEvily, A.J.; Harrison, J.H. Regulation of mitochondrial malate dehydrogenase. Evidence for an allosteric citrate-binding site. J. Biol. Chem. 1982, 257, 13233-13239. [PubMed]

112. Fahien, L.A.; Kmiotek, E.H.; MacDonald, M.J.; Fibich, B.; Mandic, M. Regulation of malate dehydrogenase activity by glutamate, citrate, alpha-ketoglutarate, and multienzyme interaction. J. Biol. Chem. 1988, 263, 10687-10697. [PubMed]

113. Gelpi, J.L.; Dordal, A.; Montserrat, J.; Mazo, A.; Cortes, A. Kinetic studies of the regulation of mitochondrial malate dehydrogenase by citrate. Biochem. J. 1992, 283, 289-297. [CrossRef] [PubMed]

114. Morgunov, I.; Srere, P.A. Interaction between citrate synthase and malate dehydrogenase. Substrate channeling of oxaloacetate. J. Biol. Chem. 1998, 273, 29540-29544. [CrossRef] [PubMed]

115. Mansouri, S.; Shahriari, A.; Kalantar, H.; Moini Zanjani, T.; Haghi Karamallah, M. Role of malate dehydrogenase in facilitating lactate dehydrogenase to support the glycolysis pathway in tumors. Biomed. Rep. 2017, 6, 463-467. [CrossRef] [PubMed]

116. Liu, Q.; Harvey, C.T.; Geng, H.; Xue, C.; Chen, V.; Beer, T.M.; Qian, D.Z. Malate dehydrogenase 2 confers docetaxel resistance via regulations of jnk signaling and oxidative metabolism. Prostate 2013, 73, 1028-1037. [CrossRef] 
117. Lee, K.; Ban, H.S.; Naik, R.; Hong, Y.S.; Son, S.; Kim, B.K.; Xia, Y.; Song, K.B.; Lee, H.S.; Won, M. Identification of malate dehydrogenase 2 as a target protein of the hif-1 inhibitor lw6 using chemical probes. Angew. Chem. 2013, 52, 10286-10289. [CrossRef]

118. Iacobazzi, V.; Infantino, V. Citrate-new functions for an old metabolite. Biol. Chem. 2014, 395, 387-399. [CrossRef]

119. Iacobazzi, V.; Infantino, V.; Palmieri, F. Epigenetic mechanisms and sp1 regulate mitochondrial citrate carrier gene expression. Biochem. Biophys. Res. Commun. 2008, 376, 15-20. [CrossRef]

120. Infantino, V.; Pierri, C.L.; Iacobazzi, V. Metabolic routes in inflammation: The citrate pathway and its potential as therapeutic target. In Current Medicinal Chemistry; BenthamScience: Sharjah, UAE, 2018.

121. Iacobazzi, V.; Infantino, V.; Bisaccia, F.; Castegna, A.; Palmieri, F. Role of foxa in mitochondrial citrate carrier gene expression and insulin secretion. Biochem. Biophys. Res. Commun. 2009, 385, 220-224. [CrossRef]

122. Infantino, V.; Convertini, P.; Cucci, L.; Panaro, M.A.; Di Noia, M.A.; Calvello, R.; Palmieri, F.; Iacobazzi, V. The mitochondrial citrate carrier: A new player in inflammation. Biochem. J. 2011, 438, 433-436. [CrossRef] [PubMed]

123. Infantino, V.; Iacobazzi, V.; Menga, A.; Avantaggiati, M.L.; Palmieri, F. A key role of the mitochondrial citrate carrier (slc25a1) in tnfalpha- and ifngamma-triggered inflammation. Biochim. Biophys. Acta 2014, 1839, 1217-1225. [CrossRef] [PubMed]

124. Infantino, V.; Iacobazzi, V.; Palmieri, F.; Menga, A. Atp-citrate lyase is essential for macrophage inflammatory response. Biochem. Biophys. Res. Commun. 2013, 440, 105-111. [CrossRef] [PubMed]

125. Lewis, C.A.; Parker, S.J.; Fiske, B.P.; McCloskey, D.; Gui, D.Y.; Green, C.R.; Vokes, N.I.; Feist, A.M.; Vander Heiden, M.G.; Metallo, C.M. Tracing compartmentalized nadph metabolism in the cytosol and mitochondria of mammalian cells. Mol. Cell 2014, 55, 253-263. [CrossRef] [PubMed]

126. Fan, J.; Ye, J.; Kamphorst, J.J.; Shlomi, T.; Thompson, C.B.; Rabinowitz, J.D. Quantitative flux analysis reveals folate-dependent nadph production. Nature 2014, 510, 298-302. [CrossRef] [PubMed]

127. Wang, M.; Sun, S.; Neufeld, C.I.; Perez-Ramirez, B.; Xu, Q. Reactive oxygen species-responsive protein modification and its intracellular delivery for targeted cancer therapy. Angew. Chem. 2014, 53, 13444-13448. [CrossRef]

128. Wen, D.; Liu, D.; Tang, J.; Dong, L.; Liu, Y.; Tao, Z.; Wan, J.; Gao, D.; Wang, L.; Sun, H.; et al. Malic enzyme 1 induces epithelial-mesenchymal transition and indicates poor prognosis in hepatocellular carcinoma. Tumour Biol. J. Int. Soc. Oncodev. Biol. Med. 2015, 36, 6211-6221. [CrossRef]

129. Lu, Y.X.; Ju, H.Q.; Liu, Z.X.; Chen, D.L.; Wang, Y.; Zhao, Q.; Wu, Q.N.; Zeng, Z.L.; Qiu, H.B.; Hu, P.S.; et al. Me1 regulates nadph homeostasis to promote gastric cancer growth and metastasis. Cancer Res. 2018, 78, 1972-1985. [CrossRef]

130. Zheng, F.J.; Ye, H.B.; Wu, M.S.; Lian, Y.F.; Qian, C.N.; Zeng, Y.X. Repressing malic enzyme 1 redirects glucose metabolism, unbalances the redox state, and attenuates migratory and invasive abilities in nasopharyngeal carcinoma cell lines. Chin. J. Cancer 2012, 31, 519-531. [CrossRef]

131. Chakrabarti, G. Mutant kras associated malic enzyme 1 expression is a predictive marker for radiation therapy response in non-small cell lung cancer. Radiat. Oncol. 2015, 10, 145. [CrossRef]

132. Vander Heiden, M.G.; DeBerardinis, R.J. Understanding the intersections between metabolism and cancer biology. Cell 2017, 168, 657-669. [CrossRef] [PubMed]

133. Palmieri, F. The mitochondrial transporter family slc25: Identification, properties and physiopathology. Mol. Asp. Med. 2013, 34, 465-484. [CrossRef] [PubMed]

134. Del Arco, A.; Morcillo, J.; Martinez-Morales, J.R.; Galian, C.; Martos, V.; Bovolenta, P.; Satrustegui, J. Expression of the aspartate/glutamate mitochondrial carriers aralar1 and citrin during development and in adult rat tissues. Eur. J. Biochem. 2002, 269, 3313-3320. [CrossRef] [PubMed]

135. Greenhouse, W.V.; Lehninger, A.L. Occurrence of the malate-aspartate shuttle in various tumor types. Cancer Res. 1976, 36, 1392-1396. [PubMed]

136. Convertini, P.; Todisco, S.; De Santis, F.; Pappalardo, I.; Iacobazzi, D.; Castiglione Morelli, M.A.; Fondufe-Mittendorf, Y.N.; Martelli, G.; Palmieri, F.; Infantino, V. Transcriptional regulation factors of the human mitochondrial aspartate/glutamate carrier gene, isoform 2 (slc25a13): Usf1 as basal factor and foxa2 as activator in liver cells. Int. J. Mol. Sci. 2019, 20, 1888. [CrossRef] [PubMed] 
137. Infantino, V.; Dituri, F.; Convertini, P.; Santarsiero, A.; Palmieri, F.; Todisco, S.; Mancarella, S.; Giannelli, G.; Iacobazzi, V. Epigenetic upregulation and functional role of the mitochondrial aspartate/glutamate carrier isoform 1 in hepatocellular carcinoma. Biochim. Biophys. Acta Mol. Basis Dis. 2019, 1865, 38-47. [CrossRef]

138. Fernandez-Alvarez, A.; Llorente-Izquierdo, C.; Mayoral, R.; Agra, N.; Bosca, L.; Casado, M.; Martin-Sanz, P. Evaluation of epigenetic modulation of cyclooxygenase-2 as a prognostic marker for hepatocellular carcinoma. Oncogenesis 2012, 1, e23. [CrossRef]

139. Tian, Y.; Wong, V.W.; Chan, H.L.; Cheng, A.S. Epigenetic regulation of hepatocellular carcinoma in non-alcoholic fatty liver disease. Semin. Cancer Biol. 2013, 23, 471-482. [CrossRef]

140. Patel, D.; Menon, D.; Bernfeld, E.; Mroz, V.; Kalan, S.; Loayza, D.; Foster, D.A. Aspartate rescues s-phase arrest caused by suppression of glutamine utilization in kras-driven cancer cells. J. Biol. Chem. 2016, 291, 9322-9329. [CrossRef]

141. Schoors, S.; Bruning, U.; Missiaen, R.; Queiroz, K.C.; Borgers, G.; Elia, I.; Zecchin, A.; Cantelmo, A.R.; Christen, S.; Goveia, J.; et al. Fatty acid carbon is essential for dntp synthesis in endothelial cells. Nature 2015, 520, 192-197. [CrossRef]

142. Lopez-Rios, F.; Sanchez-Arago, M.; Garcia-Garcia, E.; Ortega, A.D.; Berrendero, J.R.; Pozo-Rodriguez, F.; Lopez-Encuentra, A.; Ballestin, C.; Cuezva, J.M. Loss of the mitochondrial bioenergetic capacity underlies the glucose avidity of carcinomas. Cancer Res. 2007, 67, 9013-9017. [CrossRef] [PubMed]

143. Weinberg, S.E.; Chandel, N.S. Targeting mitochondria metabolism for cancer therapy. Nat. Chem. Biol. 2015, 11, 9-15. [CrossRef] [PubMed]

144. Sullivan, L.B.; Gui, D.Y.; Hosios, A.M.; Bush, L.N.; Freinkman, E.; Vander Heiden, M.G. Supporting aspartate biosynthesis is an essential function of respiration in proliferating cells. Cell 2015, 162, 552-563. [CrossRef] [PubMed]

145. Amoedo, N.D.; Punzi, G.; Obre, E.; Lacombe, D.; De Grassi, A.; Pierri, C.L.; Rossignol, R. Agc1/2, the mitochondrial aspartate-glutamate carriers. Biochim. Biophys. Acta 2016, 1863, 2394-2412. [CrossRef]

146. Palmieri, L.; Pardo, B.; Lasorsa, F.M.; del Arco, A.; Kobayashi, K.; Iijima, M.; Runswick, M.J.; Walker, J.E.; Saheki, T.; Satrustegui, J.; et al. Citrin and aralar1 are $\mathrm{Ca}^{2+}$-stimulated aspartate/glutamate transporters in mitochondria. EMBO J. 2001, 20, 5060-5069. [CrossRef]

147. Rabinovich, S.; Adler, L.; Yizhak, K.; Sarver, A.; Silberman, A.; Agron, S.; Stettner, N.; Sun, Q.; Brandis, A.; Helbling, D.; et al. Diversion of aspartate in ass1-deficient tumours fosters de novo pyrimidine synthesis. Nature 2015, 527, 379-383. [CrossRef]

148. Alkan, H.F.; Walter, K.E.; Luengo, A.; Madreiter-Sokolowski, C.T.; Stryeck, S.; Lau, A.N.; Al-Zoughbi, W.; Lewis, C.A.; Thomas, C.J.; Hoefler, G.; et al. Cytosolic aspartate availability determines cell survival when glutamine is limiting. Cell Metab. 2018, 28, 706-720. [CrossRef]

149. Fuchs, B.C.; Bode, B.P. Stressing out over survival: Glutamine as an apoptotic modulator. J. Surg. Res. 2006, 131, 26-40. [CrossRef]

150. Fuchs, B.C.; Bode, B.P. Amino acid transporters asct 2 and lat1 in cancer: Partners in crime? Semin. Cancer Biol. 2005, 15, 254-266. [CrossRef]

151. Mullen, A.R.; Wheaton, W.W.; Jin, E.S.; Chen, P.H.; Sullivan, L.B.; Cheng, T.; Yang, Y.; Linehan, W.M.; Chandel, N.S.; DeBerardinis, R.J. Reductive carboxylation supports growth in tumour cells with defective mitochondria. Nature 2011, 481, 385-388. [CrossRef]

152. Chen, J.Q.; Russo, J. Dysregulation of glucose transport, glycolysis, tca cycle and glutaminolysis by oncogenes and tumor suppressors in cancer cells. Biochim. Biophys. Acta 2012, 1826, 370-384. [CrossRef] [PubMed]

153. Chen, L.; Cui, H. Targeting glutamine induces apoptosis: A cancer therapy approach. Int. J. Mol. Sci. 2015, 16, 22830-22855. [CrossRef] [PubMed]

154. Xiang, Y.; Stine, Z.E.; Xia, J.; Lu, Y.; O’Connor, R.S.; Altman, B.J.; Hsieh, A.L.; Gouw, A.M.; Thomas, A.G.; Gao, P.; et al. Targeted inhibition of tumor-specific glutaminase diminishes cell-autonomous tumorigenesis. J. Clin. Investig. 2015, 125, 2293-2306. [CrossRef] [PubMed]

155. DeWaal, D.; Nogueira, V.; Terry, A.R.; Patra, K.C.; Jeon, S.M.; Guzman, G.; Au, J.; Long, C.P.; Antoniewicz, M.R.; Hay, N. Hexokinase-2 depletion inhibits glycolysis and induces oxidative phosphorylation in hepatocellular carcinoma and sensitizes to metformin. Nat. Commun. 2018, 9, 446. [CrossRef] [PubMed]

156. Bjornson, E.; Mukhopadhyay, B.; Asplund, A.; Pristovsek, N.; Cinar, R.; Romeo, S.; Uhlen, M.; Kunos, G.; Nielsen, J.; Mardinoglu, A. Stratification of hepatocellular carcinoma patients based on acetate utilization. Cell Rep. 2015, 13, 2014-2026. [CrossRef] [PubMed] 
157. Baggetto, L.G. Deviant energetic metabolism of glycolytic cancer cells. Biochimie 1992, 74, 959-974. [CrossRef]

158. Guay, C.; Madiraju, S.R.; Aumais, A.; Joly, E.; Prentki, M. A role for atp-citrate lyase, malic enzyme, and pyruvate/citrate cycling in glucose-induced insulin secretion. J. Biol. Chem. 2007, 282, 35657-35665. [CrossRef]

159. Sauer, L.A.; Dauchy, R.T.; Nagel, W.O.; Morris, H.P. Mitochondrial malic enzymes. Mitochondrial $\operatorname{nad}(\mathrm{p})+$-dependent malic enzyme activity and malate-dependent pyruvate formation are progression-linked in morris hepatomas. J. Biol. Chem. 1980, 255, 3844-3848.

160. Wen, Y.; Xu, L.; Chen, F.L.; Gao, J.; Li, J.Y.; Hu, L.H.; Li, J. Discovery of a novel inhibitor of nad(p)(+)-dependent malic enzyme (me2) by high-throughput screening. Acta Pharmacol. Sin. 2014, 35, 674-684. [CrossRef]

161. Gao, X.; Sheng, Y.; Yang, J.; Wang, C.; Zhang, R.; Zhu, Y.; Zhang, Z.; Zhang, K.; Yan, S.; Sun, H.; et al. Osteopontin alters DNA methylation through up-regulating DNMT1 and sensitizes CD133+/CD44+ cancer stem cells to 5 azacytidine in hepatocellular carcinoma. J. Exp. Clin. Cancer Res. 2018, 37, 179. [CrossRef]

162. Xie, C.R.; Li, Z.; Sun, H.G.; Wang, F.Q.; Sun, Y.; Zhao, W.X.; Zhang, S.; Zhao, W.X.; Wang, X.M.; Yin, Z.Y. Mutual regulation between chd5 and ezh2 in hepatocellular carcinoma. Oncotarget 2015, 6, 40940-40952. [CrossRef] [PubMed]

163. Yang, F.; Lv, L.Z.; Cai, Q.C.; Jiang, Y. Potential roles of ezh2, bmi-1 and mir-203 in cell proliferation and invasion in hepatocellular carcinoma cell line hep3b. World J. Gastroenterol. 2015, 21, 13268-13276. [CrossRef] [PubMed]

164. Bricambert, J.; Miranda, J.; Benhamed, F.; Girard, J.; Postic, C.; Dentin, R. Salt-inducible kinase 2 links transcriptional coactivator $\mathrm{p} 300$ phosphorylation to the prevention of chrebp-dependent hepatic steatosis in mice. J. Clin. Investig. 2010, 120, 4316-4331. [CrossRef] [PubMed]

165. Li, M.; Luo, R.Z.; Chen, J.W.; Cao, Y.; Lu, J.B.; He, J.H.; Wu, Q.L.; Cai, M.Y. High expression of transcriptional coactivator $\mathrm{p} 300$ correlates with aggressive features and poor prognosis of hepatocellular carcinoma. J. Transl. Med. 2011, 9, 5. [CrossRef]

166. Dierks, T.; Stappen, R.; Salentin, A.; Kramer, R. Probing the active site of the reconstituted aspartate/glutamate carrier from bovine heart mitochondria: Carbodiimide-catalyzed acylation of a functional lysine residue. Biochim. Biophys. Acta 1992, 1103, 13-24. [CrossRef]

167. Fuchs, B.C.; Perez, J.C.; Suetterlin, J.E.; Chaudhry, S.B.; Bode, B.P. Inducible antisense rna targeting amino acid transporter atb0/asct2 elicits apoptosis in human hepatoma cells. Am. J. Physiol. Gastrointest. Liver Physiol. 2004, 286, G467-G478. [CrossRef]

168. Cardaci, S.; Rizza, S.; Filomeni, G.; Bernardini, R.; Bertocchi, F.; Mattei, M.; Paci, M.; Rotilio, G.; Ciriolo, M.R. Glutamine deprivation enhances antitumor activity of 3-bromopyruvate through the stabilization of monocarboxylate transporter-1. Cancer Res. 2012, 72, 4526-4536. [CrossRef]

169. Wang, Q.; Hardie, R.A.; Hoy, A.J.; van Geldermalsen, M.; Gao, D.; Fazli, L.; Sadowski, M.C.; Balaban, S.; Schreuder, M.; Nagarajah, R.; et al. Targeting asct2-mediated glutamine uptake blocks prostate cancer growth and tumour development. J. Pathol. 2015, 236, 278-289. [CrossRef]

170. Imai, H.; Kaira, K.; Oriuchi, N.; Shimizu, K.; Tominaga, H.; Yanagitani, N.; Sunaga, N.; Ishizuka, T.; Nagamori, S.; Promchan, K.; et al. Inhibition of l-type amino acid transporter 1 has antitumor activity in non-small cell lung cancer. Anticancer Res. 2010, 30, 4819-4828.

171. Xu, P.; Oosterveer, M.H.; Stein, S.; Demagny, H.; Ryu, D.; Moullan, N.; Wang, X.; Can, E.; Zamboni, N.; Comment, A.; et al. Lrh-1-dependent programming of mitochondrial glutamine processing drives liver cancer. Genes Dev. 2016, 30, 1255-1260. [CrossRef]

172. Gross, M.I.; Demo, S.D.; Dennison, J.B.; Chen, L.; Chernov-Rogan, T.; Goyal, B.; Janes, J.R.; Laidig, G.J.; Lewis, E.R.; Li, J.; et al. Antitumor activity of the glutaminase inhibitor cb-839 in triple-negative breast cancer. Mol. Cancer Ther. 2014, 13, 890-901. [CrossRef] [PubMed]

(C) 2019 by the authors. Licensee MDPI, Basel, Switzerland. This article is an open access article distributed under the terms and conditions of the Creative Commons Attribution (CC BY) license (http://creativecommons.org/licenses/by/4.0/). 